\title{
Role of plankton in the carbon and nitrogen budgets of Santa Monica Basin, California
}

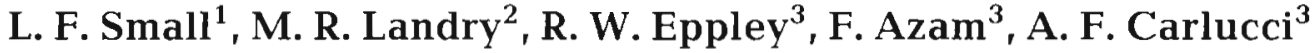 \\ ${ }^{1}$ College of Oceanography, Oregon State University, Corvallis, Oregon 97331, USA \\ ${ }^{2}$ Department of Oceanography and Hawaii Institute of Geophysics, University of Hawaii at Manoa, Honolulu, Hawaii 96822 , \\ USA \\ ${ }^{3}$ Institute of Marine Resources, A-018, Scripps Institution of Oceanography, La Jolla, California 92093, USA
}

\begin{abstract}
The photic zone portions of a particle budget, resolved as carbon and, through appropriate $\mathrm{C}: \mathrm{N}$ ratios, as nitrogen, are reported for the Santa Monica Basin, a $900 \mathrm{~m}$ deep basin in Santa Monica Bay, within the Southern California Bight west of Los Angeles, California. Included are standing stocks of phytoplankton, bacteria and zooplankton, primary production, new production, and particle flux leaving the photic zone. These are compared with rates of fecal pellet production by macrozooplankton and consumption by bacteria and zooplankton within the photic zone using data from 3 October cruises and 2 spring cruises, 1985 to 1987 . Because new production took place primarily within the nitracline, in the lower portion of the photic zone, the productivity and zooplankton measurements and some of the bacteria measurements were also made above and within the nitracline. Comparison of $C$ and $N$ fluxes out of the photic zone with standing stocks of particulate $C$ (PC) and N (PN) indicated that PC had a shorter residence time than PN in the photic zone during both spring and fall. The carbon flux was also a greater fraction of daily primary production than was the product of the PN flux and the Redfield ratio. This conservation of nitrogen, relative to carbon, may be a general feature of oligotrophic surface waters, and probably is largely accomplished by preferential solubilization and assimilation of nitrogen by zooplankton and microheterotrophs. Such differential cycling of $C$ and $N$ suggests the possibility of incipient $\mathrm{N}$-limitation of phytoplankton growth rates in spite of Redfield-like $\mathrm{C}: \mathrm{N}$ ratios for the bulk suspended particulates. Increases in phytoplankton $C: N$ ratios related to $N$-stress could be masked by relative increases in bacterial biomass with relatively low $C: N$ composition ratios. A representative budiget for particulate carbon in the photic zone is shown to illustrate rates, routes and reservoirs of PC and to point up the terms required to balance the budget. In addition to showing the greater flux (shorter recycling time) of $\mathrm{PC}$ relative to $\mathrm{PN}$ in the photic zone, the budget showed that most of the primary production (either as $\mathrm{C}$ or $\mathrm{N}$ ) was recycled within the photic zone, which implied heavy grazing by organisms $<200 \mu \mathrm{m}$ and/or by macrozooplankton that produced slowly settling fecal debris. Zooplankton food intake rate was always greater than the new production rate in the photic zone, and was usually $>20 \%$ of the primary production rate. Estimates of bacterial demand for DOC suggested that about half of the primary production was ultimately processed in the photic zone by bacteria. The transformations of PC by microheterotrophs, and the ultimate partitioning of total PC flux into components due to direct settling of bacteria, phytoplankton, and detrital particles not processed by small herbivores, are unknown at present.
\end{abstract}

\section{INTRODUCTION}

The Santa Monica Bay region off Los Angeles, California (Fig. 1) includes a shallow shelf, $21 \mathrm{~km}$ at its widest point, rising from the $922 \mathrm{~m}$ deep Santa Monica Basin. The latter is one of several deep basins in the continental borderland off Southern California, and one of the more significant ones in terms of anthropogenic inputs (Bascom 1983-1984). The US Department of Energy recently initiated a multidisciplinary oceanographic study of the Carlifornia basins in order, among other things, to evaluate the cycling and mineralization of materials in the basins. We present here an attempt to evaluate the dynamics and fate of particulate organic matter in the photic zone overlying Santa Monica Basin during spring and fall seasons This report is a contribution to the US Department of Energy (USDOE) California Basins Study (CaBS).

Plankton net tows have been made at several stations in the bay for many years by staff of the City of Los Angeles. The amount of plankton was related to the historical rate of primary production inferred from sea- 


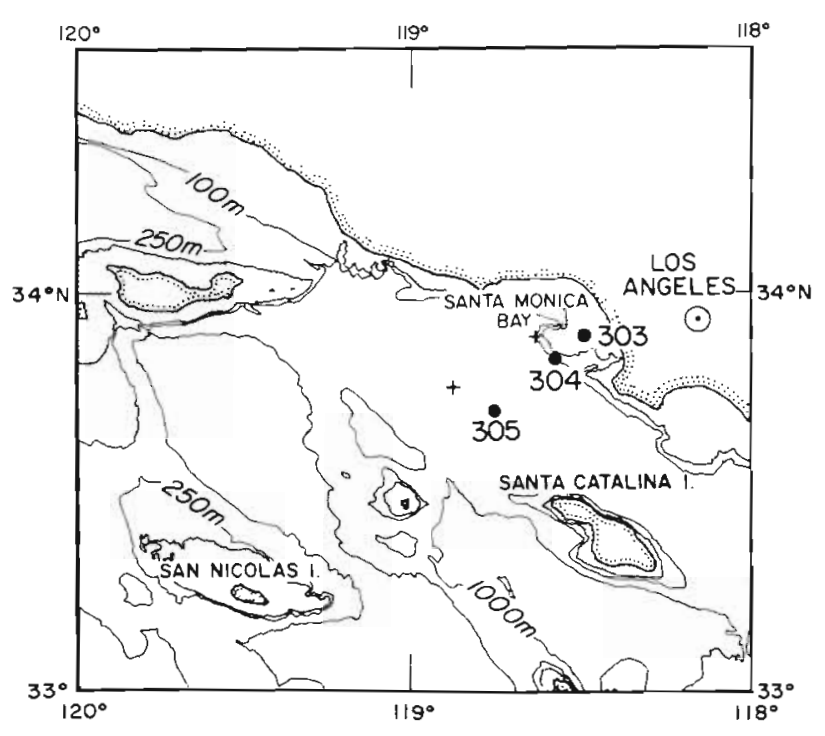

Fig. 1. Santa Monica Basin, showing the location of the principal study site (Stn SCBS 305) plus 2 other inshore stations (303 and 304) used for comparison to Stn 305

sonal and interannual anomalies in ocean temperature (Smith \& Eppley 1982). Plankton standing stocks have also been studied in water bottle samples on cruises taken 2 to 4 times per year since 1974 [in the Southern California Bight Study (SCBS), also supported by the USDOE], using mainly data on chlorophyll and particulate carbon and nitrogen. Those biomass measures were higher on the shelf off Santa Monica Bay than at other nearshore locations studied in the Bight, probably as a consequence of eutrophication (Eppley 1986). Plankton biomass and rates of photosynthesis showed considerable non-seasonal variability in the SCBS study, and the variability at a station over the center of Santa Monica Basin (Stn SCBS 305; Fig. 1) was in phase with that at other offshore stations in the Southern California Bight (G. A. Jackson unpubl.). This result suggested that temporal variation in physical forcing predominates over terrestrial inputs in determining the variability of plankton biomass and production in the Basin.

An overview of the physical setting of the study area was given by Carlucci et al. (1986a) and Jackson (1986). It is noteworthy that the inner portion of the Southern California Bight, including the waters over Santa Monica Basin, is typically warmer than the waters to the north or offshore in the main flow of the California Current. This characteristic stands out in satellite temperature images of the region. Low chlorophyll values, seen in ocean color images, show spatial and temporal variation similar to that of sea surface temperature. Thus, warm water and low chlorophyll co-occur in the inner Bight. Within the inner Bight, however, there are general onshore (high) to offshore (low) gradients in plankton biomass and activity (Mullin 1986).

Bacterial biomass and activity were studied earlier and compared with phytoplankton chlorophyll and photosynthesis (Azam 1986). Eppley \& Holm-Hansen (1986) summarized the previous SCBS study of primary production processes, and Williams (1986) reviewed the chemistry of dissolved and particulate materials. The plankton and nutrient data indicate that the inner Bight is relatively oligotrophic compared to other coastal waters of the west coast of North America. The photic zone is 2 layered with a nitrate-depleted upper layer and a nitrate-rich layer within the nitracline beneath. This characteristic structure guided the present sampling program. Because new production would be expected only in the lower, nitrate-rich layer, we attempted to separately assess biomass and production rates in the 2 layers in order to better assess the upper-water-column dynamics.

\section{METHODS}

Station locations and cruises. The present paper emphasizes data collected at SCBS $305\left(33^{\circ} 45^{\prime} \mathrm{N}\right.$, $118^{\circ} 48^{\prime} \mathrm{W}$; Fig. 1) which is located over the approximate deepest part of Santa Monica Basin (905 m). For comparison we also examined primary production at a shallow station (SCBS 303; 56 m) within Santa Monica Bay and an intermediate station (SCBS 304; $206 \mathrm{~m}$ ). Our major analyses centered on 5 cruises, of which 3 were in fall (CaBS-1 in October 1985, CaBS-4 in October 1986, and CaBS-7 in October 1987) and 2 were in spring (CaBS-3 in May 1986 and CaBS-5 in April 1987). During these cruises we had full suites of data on phytoplankton and zooplankton processes. Historical data for the March to May and September to November periods at SCBS 305 were also examined for comparison to our 5 data sets.

${ }^{14} \mathrm{C}$ primary production. Water samples for primary production and new production rate estimates, and for nutrient and particulate concentrations, were collected with 51 Niskin bottles (acid-cleaned, with silicone tubing and $O$-rings) at 6 depths in the photic zone. First, a secchi disc was lowered to define the depth of the photic zone, taken here as 3 times the secchi depth (= depth of $1 \%$ surface light intensity). Assuming a constant diffuse attenuation coefficient, sampling depths were chosen to correspond to the light transmission of the neutral density filters of the deck incubators. On some cruises an underwater quanta-meter provided this information directly. The water samples were placed in 200 to $300 \mathrm{ml}$ acid-cleaned polycarbonate bottles and inoculated with ca $4 \mu \mathrm{Ci}$ of ${ }^{14} \mathrm{C}$ bicarbonate per bottle. The bottles were then incubated for $24 \mathrm{~h}$ in a surface-water-cooled deck 
incubator or attached to an in situ line on a drifting sediment trap array. Following incubation, particulates in the water samples were filtered onto GF/F glass fiber filters, acid-fumed, and analyzed for ${ }^{14} \mathrm{C}$ uptake by scintillation counting. GF/F filters were used to minimize passage of picoplankton, although it was recognized that some fraction, perhaps 20 to $30 \%$, of the picoplankton passes through these filters ( $\mathrm{Li} 1986$ ).

Particulates and nutrients. Chlorophyll subsamples from the Niskin bottles were filtered onto GF/F filters, extracted in $90 \%$ acetone, and analyzed for fluorescence, before and after acidification, using a calibrated Turner 111 fluorometer. Samples for particulate organic carbon and nitrogen were filtered on precombusted GF/F filters and analyzed with an HP model 185B CHN analyzer. Nutrients (nitrate, nitrite, silicic acid and phosphate) were measured spectrophotometrically by the methods described in Strickland \& Parsons (1972). For nanomolar concentrations found above the nitracline, nitrate was measured by the chemiluminescent method of Garside (1982).

New production and residence time. Water samples for determination of nitrate assimilation by phytoplankton were transferred from the Niskin bottles to acidcleaned polycarbonate bottles, placed in the deck incubator and subsampled for nitrate analysis at time zero, dusk, dawn, and after $24 \mathrm{~h}$. Nitrate was usually consumed during these incubations, but sometimes, when nitrate concentrations were low, nitrate actually increased, perhaps due to nitrification. In those cases, nitrate assimilation was taken as zero. When nitrate was consumed, the carbon equivalent of its assimilation by the phytoplankton was calculated using the Redfield C: $N$ ratio. Because it was possible to process only 2 or 3 sampling depths with this frequency of nitrate analysis, rather than the full 6-bottle depth profile, we prepared an algorithm relating the observed $f$-ratio and ambient nitrate concentration. This allowed the carbon equivalent of nitrate assimilation (i.e. the rate of new production) to be estimated from any sample with both nitrate and ${ }^{14} \mathrm{C}$ assimilation measurements. The measured nitrate utilization rates were used in preference to the calculated values whenever they were available. The $f$-ratio is the ratio of new production to total ${ }^{14} \mathrm{C}$ production. Theoretically it can vary between 0 and 1 , but its maximum value in the historical data from this region (Eppley et al. 1979) is 0.64 (Harrison et al. 1987). The product of the f-ratio and ${ }^{14} \mathrm{C}$ production is the new production. Since new production is equivalent to the sinking flux of biogenic particles, in a steady state system, the residence time of biogenic particulate organic carbon (POC) produced in the photic zone is the quotient of the ambient biogenic $\mathrm{POC} /($ rate of new production), as per Eppley et al. (1983). Biogenic particulate carbon (PC) is very nearly the same as biogenic POC in Santa Monica Basin because of the paucity of carbonate-containing organisms in the suspended-particle field; thus, either acidfumed samples (POC) or non-fumed samples (PC) can be used interchangeably without great loss of accuracy. However, biogenic POC or PC is rarely the equivalent of total measured $\mathrm{POC}$ or $\mathrm{PC}$, particularly in coastal environments in which one expects contributions of detrital carbon from terrigenous sources. We have assumed that biogenic particulate nitrogen (PON or $\mathrm{PN}$ ) is more representative of the organic matter produced in the photic zone in Santa Monica Basin, and have thus derived POC concentrations through use of the Redfield ratio. POC residence times were calculated from these derived POC values.

Particulate flux. Flux rates of particulate carbon and nitrogen were measured at SCBS 305 from material collected by sediment traps in a standard depth range of 90 to $100 \mathrm{~m}$. This range lies below the base of the photic zone in all seasons, and out of the strata where high concentrations of suspended particulates can bias trap collections during short deployments. Prior to October 1987, we used small cylindrical traps attached individually at 90 and $100 \mathrm{~m}$ on a free-drifting array (Welshmeyer \& Lorenzen 1985). The traps are made of PVC (polyvinyl chloride) and have a mouth area of about $41 \mathrm{~cm}^{2}$, an aspect (height: width) ratio of $3: 1$, and a volume of $0.9 \mathrm{l}$. In October 1987, we used traps (designed by N. Welshmeyer) which were substantially identical to those used previously except for a greater aspect ratio $(5: 1)$ and trap volume $(1.31)$. These traps were deployed in triplicate at $100 \mathrm{~m}$. Before deployment, the traps were cleaned with ethanol, rinsed with freshwater, and filled with refrigerated, filtered seawater and additional salt ( $\mathrm{NaCl}$ ) to establish a density gradient. The deployment interval for the array was 24 $h$, beginning before sunrise. A time-released messenger system closed the traps before recovery.

Following recovery, zooplankton were removed from the trap material by microscopical sorting. The trap contents were then thoroughly mixed and duplicate subsamples removed for CHN analyses. These aliquots were concentrated on silver filters $(0.45 \mu \mathrm{m}$ pore size), dried at $60^{\circ} \mathrm{C}$, and analyzed with a Carlo Erba Elemental Analyzer. Silver filters were used in order to minimize adsorption of dissolved organic carbon.

Although the presence or absence of preservatives in sediment traps can have important implications for the utilization of collected organic material by microbes and swimmers (Knauer et al. 1984), these effects were insignificant for the short-duration deployments considered here. For example, Nelson et al. (1987) found no consistent differences between flux estimates for formalin-preserved and unpreserved traps deployed in the Santa Monica Basin for $2.5 \mathrm{~d}$. During $3 \mathrm{~d}$ experi- 
ments however, we have noted that unpreserved traps lost organic material at rates of about $4 \% \mathrm{C}$ and $2 \% \mathrm{~N}$ per day relative to traps preserved with $\mathrm{HgCl}$, and $1 \% \mathrm{C}$ and $0 \% \mathrm{~N}$ relative to traps preserved with sodium azide (Landry, unpubl. data from April. 1987). The mean coefficient of variation for flux estimates among replicate traps was about $15 \%$. This is comparable to estimates of $13.5 \%$ and $20.2 \%$ reported by Nelson et al. (1987).

Bacteria and microflagellates. Samples were obtained with clean 51 Niskin bottles at 2 or 3 depths in the photic zone during May 1986 and October 1986. Immediately after the bottles were brought up, subsamples were taken for determining bacteria and microflagellate abundances and biomasses. The samples were preserved with filtered, borate-buffered formalin at $2 \%$ final concentration. Procedures for counting and determining biomass have been reported (Hobbie et al. 1977. Carlucci et al. 1986b, Lee \& Fuhrman 1987, Cho \& Azam 1988). Bacterial carbon was calculated from biovolumes according to Lee \& Fuhrman (1987), assuming that bacteria with volumes $\leq 0.07 \mu \mathrm{m}^{3}$ had $20 \mathrm{fg} \mathrm{C}$ while larger bacteria had $380 \mathrm{fg} \mathrm{C} \mathrm{mm}^{-3}$. Microflagellate biovolume was converted to cell $\mathrm{C}$ by assuming $100 \mathrm{fg} \mathrm{C} \mathrm{um}^{-3}$. Subsamples were also taken from Niskin bottles for determining bacterial production by the tritiated thymidine incorporation method (Fuhrman \& Azam 1982). The precision of our measurements was generally within $7 \pm 2 \%$ (mean $\pm 1 \mathrm{SD}$ ).

Macrozooplankton biomass. Macrozooplankton biomass from the surface to below the photic zone was estimated during each cruise from horizontal tows with closing meter nets ( $200 \mu \mathrm{m}$ mesh size). Tows of $20 \mathrm{~min}$ duration were done through at least 5 different depth strata during both day and night periods. On board ship, the contents of the cod ends of the nets were gently screened through $2000 \mu \mathrm{m}$ mesh, to remove larger animals and gelatinous forms. The remainder was screened successively through 1000, 500, and $200 \mu \mathrm{m}$ mesh, to retain 1000-2000, 500-1000, and 200-500 $\mu \mathrm{m}$ zooplankton fractions. Each fraction was quickly immersed in distilled water to dispel excess salt, then frozen at $-20^{\circ} \mathrm{C}$. In the shore-based laboratory, the fractions were dried at $60^{\circ} \mathrm{C}$ and weighed, and the carbon and nitrogen contents were determined in a Perkin-Elmer model $240 \mathrm{C}$ CHN analyzer The mean coefficient of variation for replicate tows at any given depth for a given size fraction was $18 \%$, on a carbon basis. Biomass concentrations ( $\mathrm{mg}$ dry $\mathrm{wt} \mathrm{m}^{-3}$, or $\mathrm{mg} \mathrm{C}$ $\mathrm{m}^{-3}$ ) were calculated, and biomass profiles for both night and day for each size group of zooplankton were subsequently developed. These profiles could be integrated over any chosen depth horizon to yield mg dry

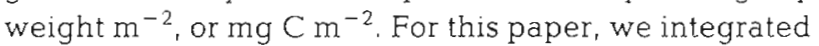
from the sea surface to the top of the nitracline, from the nitracline to the bottom of the photic zone, and from the surface to the bottom of the photic zone

Gut clearance and fecal carbon production rates. Initial gut pigment concentrations and gut clearance rates of macrozooplankton representative of the 3 size groups were determined using the gut fluorescence technique (Mackas \& Bohrer 1976, Dagg \& Wyman 1983, Kiørboe et al. 1985, Christofferson \& Jesperson 1986), with some modifications of clearance rate procedures (Ellis \& Small unpubl.). Our method was to quickly disperse unsorted zooplankton from a short net haul (after initial gentle screening through $2000 \mu \mathrm{m}$ mesh and a short settling period to separate the most robust animals) into a series of plastic cylinders containing filtered seawater. Each cylinder had an inset mesh bottom to allow fecal pellets to sink through. The cylinders were placed in a darkened, temperaturecontrolled water bath and were harvested in sequence over short time intervals to establish gut clearance rates. Gut clearance rates were expressed as fractional loss from the initial gut pigment concentration per unit time. When normalized by dry animal weight, the coefficient of variation over all size groups during all cruises averaged $27 \%$.

Fecal carbon production rates were calculated for each zooplankton size group by converting initial gut pigment concentrations to concentrations of nonassimilated carbon in the gut, and then multiplying by the appropriate fractional gut clearance rate. Conversion to non-assimilated gut carbon was done by assuming that the POC-pigment ratio in the suspended particle field was the ratio in the food of the zooplankton, and that the assimilation efficiency of ingested carbon was $70 \%$ (i.e. the 'egestion efficiency' was $30 \%$ ). This technique assumes herbivorous/omnivorous feeding (some omnivory was assumed because the POC: pigment ratio in suspended particles was always greater than that in phytoplankton alone, indicating that nonpigmented detrital particles and/or protozoans were also available as food). We collected freshly voided fecal pellets from the 3 zooplankton size groups in April 1987 and October 1987 (as per Small et al. 1979), and the $\mathrm{C}$. pigment ratios in these pellets provided a rough check on herbivory/omnivory. In April it appeared that production was predominantly by hervibores/omnivores (pellet C: pigment ratios were equivalent to $30 \%$ of the POC:pigment ratio in suspended particles). However, some carnivory was suggested in October (pellet $\mathrm{C}$ pigment ratios were higher than expected for herbivores/omnivores).

Fecal carbon production rates were initially expressed as $\mathrm{mg}$ fecal $\mathrm{C}(\mathrm{mg} \text { body } \mathrm{C})^{-1} \mathrm{~h}^{-1}$. Fractions voided during the daylight period only, and during the night only, were estimated by multipiying the hourly rates by, respectively, the number of daylight hours or 
night-time hours in the $24 \mathrm{~h}$ day during each cruise period. In separate experiments (Ellis \& Small unpubl.) we could find no significant difference between hourly rates determined from day-caught or night-caught animals. These rates were scaled to population-based rates by multiplying by the appropriate day or night carbon-based zooplankton biomasses integrated over the appropriate depth horizons. Thus, fecal carbon production rates in terms of $\mathrm{mg} \mathrm{C} \mathrm{m}{ }^{-2}$ (time period) ${ }^{-1}$ were computed for daytime and night-time periods for the 3 zooplankton size groups over the 3 selected depth horizons. Separate calculations of population-based rates over the day and night periods effectively accounted for diel vertical migrations of populations. The above rates were easily combined in convenient ways. For example, to obtain the total $24 \mathrm{~h}$ production rate of fecal carbon through the complete photic zone by $200-2000 \mu \mathrm{m}$ zooplankton, one simply adds the rates from both the day and night periods for all 3 size groups integrated over the photic depth. Such rates and rate combinations are directly comparable to integral primary and new production rates and to trapderived carbon fluxes.

\section{RESULTS}

\section{Primary production and biomass}

Eppley et al. (1985) showed that interannual variation in primary production in Santa Monica Basin is greater than seasonal variation, and such is borne out by examining historical data (since 1974) at SCBS 303, 304 and 305 (Fig. 2). The onshore-offshore gradient in primary production in the inner southern California Bight (Mullin 1986) can be observed reasonably well in Santa Monica Bay and Basin, with the most inshore station (SCBS 303) showing higher median integral production than the stations further offshore (Fig. 2). The photic zone at SCBS 305 and vicinity apparently is representative (on annual average) of the upper waters over the deep basin. In fact, if primary production rates are correlated among all 16 of the historical stations occupied in the Bight (not shown in Fig. 1), the greatest correlation occurs between the rates at SCBS 305 and the areally integrated mean primary production rate for the whole region. The variability observed over the basin is typical of the coastal waters from San Diego to Los Angeles and offshore $100 \mathrm{~km}$. Mullin (1986) also showed that there are no major zonal differences in nutrient, pigment, POC, or ATP concentrations, or in the rate of primary production seaward of $50 \mathrm{~km}$ of the coast throughout the Bight region. The interactions of processes in the upper water column at SCBS 305, therefore, are assumed to be typical of the Southern California Bight.

Data from Hickey (1986) in fall/winter suggested that particles produced at SCBS 303 would be carried northwestward alongshore, with presumably little direct effect on upper waters at SCBS 305. A transmissometer survey in May 1983 showed an apparently continuous layer, identified with the subsurface chlorophyll maximum, extending across the basin (Nelson et al. 1987). It was not clear whether the apparent continuity of the layer of particles was caused by local growth-related processes or by flow. Phytoplankton species distribution, showing strong onshore-offshore gradients but alongshore continuity (Eppley et al. 1984), suggested the former. Although separation of nearshore effects from processes in the central basin apparently is the general condition, there is some evidence to suggest that on occasion nearshore flow extends over SCBS 305. Transmissometer survey and current meter data during the October 1986 cruise (Hickey pers. comm.)

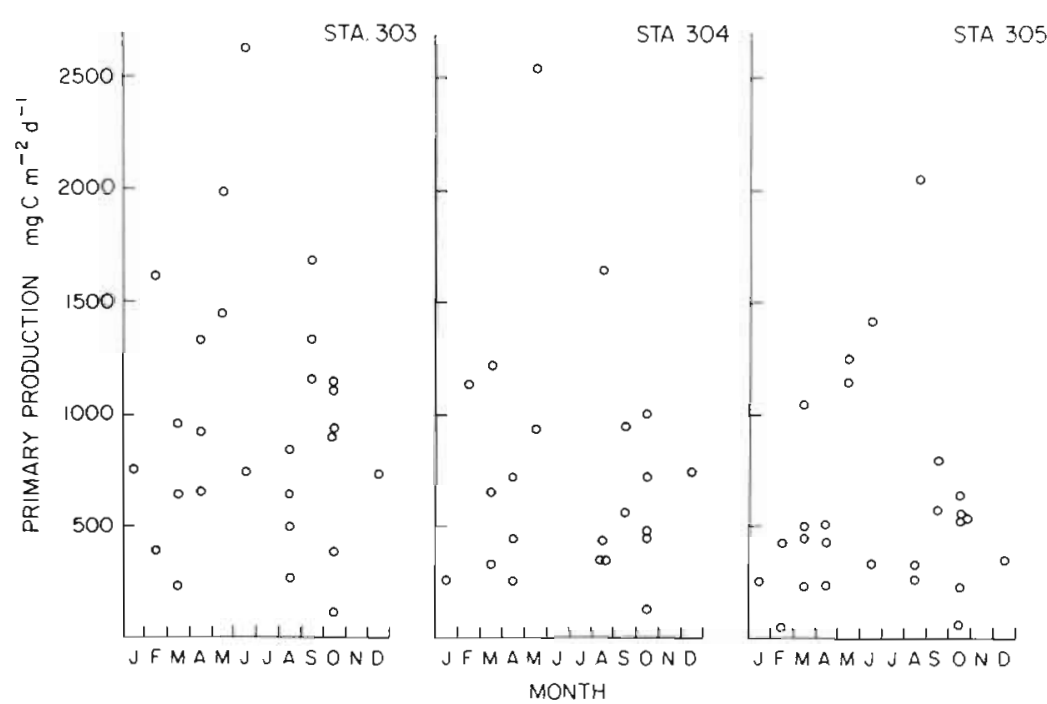

Fig. 2. Historical primary production at the 3 stations, showing the large interannual varia- 
Table 1. Historical values of selected attributes at Stn SCBS 305 in Santa Monica Basin, California, 1980 to present, for spring and fall periods. The values for the present study ( 5 dates) are identified by month and year. Zn: depth of the top of the nitracline; Ze depth of the photic zone ( $1 \%$ of light incident to the sea surface)

\begin{tabular}{|c|c|c|c|c|c|c|c|}
\hline & $\begin{array}{c}\text { Photic depth } \\
\text { Ze } \\
(\mathrm{m})\end{array}$ & $\begin{array}{l}\text { Nitracline } \\
\text { depth, } \mathrm{Zn} \\
\text { (m) }\end{array}$ & $\begin{array}{c}\text { Primary } \\
\text { production } \\
\left(\mathrm{mg} C \mathrm{~m}^{-2} \mathrm{~d}^{-1}\right)\end{array}$ & POC & $\begin{array}{c}\text { PON } \\
\left(\mathrm{mg} \mathrm{m}^{-2}\right)\end{array}$ & $\mathrm{Chl}$ & $\begin{array}{c}\text { Fraction of photic } \\
\text { zone containing } \\
\mathrm{NO}_{3}^{-} \\
{[1-(\mathrm{Zn} / \mathrm{Ze})]}\end{array}$ \\
\hline \multirow[t]{5}{*}{ Mar-May } & 49 & 34 & 914 & 7237 & 1116 & 58.1 & 0.31 \\
\hline & 45 & 30 & 1150 & 4393 & 683 & 30.3 & 0.33 \\
\hline & 36 & 26 & 1050 & 4593 & 808 & 39.4 & 0.28 \\
\hline & 53 & 28 & 730 & 3220 & 510 & 21.6 & 0.47 \\
\hline & 41 & 20 & 411 & 4283 & 753 & 26.9 & 0.51 \\
\hline May 1986 & 39 & 16 & 1254 & 8787 & 1547 & 62.0 & 0.59 \\
\hline Apr 1987 & 51 & 35 & 521 & 5018 & 716 & 24.2 & 0.31 \\
\hline \multirow[t]{3}{*}{ Sep-Nov } & 60 & 16 & 213 & 2100 & 306 & 18.1 & 0.73 \\
\hline & 45 & 33 & 517 & 3173 & 542 & 28.2 & 0.27 \\
\hline & 55 & 55 & 321 & 2663 & 397 & 23.1 & 0.0 \\
\hline \multirow[t]{2}{*}{ Oct 1985} & 48 & 36 & 531 & 3374 & 579 & 19.9 & 0.25 \\
\hline & 26 & 27 & 800 & 4134 & 592 & 38.7 & 0.0 \\
\hline Oct 1986 & 66 & 27 & 556 & 2451 & 512 & 13.0 & 0.59 \\
\hline Oct 1987 & 72 & 50 & 634 & 3836 & 701 & 18.1 & 0.31 \\
\hline \multicolumn{8}{|l|}{ Medians } \\
\hline Mar-May & 45 & 26 & 1050 & 4493 & 735 & 30.3 & 0.33 \\
\hline Sep-Nov & 54 & 33 & 531 & 3173 & 542 & 19.9 & 0.27 \\
\hline \multicolumn{8}{|l|}{ Ranges } \\
\hline Mar-May & $36-53$ & $16-35$ & $411-1254$ & $3220-8787$ & $510-1547$ & $21.6-62.0$ & $0.28-0.59$ \\
\hline Sep-Nov & $26-72$ & $16-55$ & $213-800$ & $2100-4134$ & $306-701$ & $13.0-38.7$ & $0.0-0.73$ \\
\hline
\end{tabular}

indicated that the period was one of anomalous transport of suspended particulates from the broad San Pedro shelf region south of Los Angeles (Fig. 1) toward SCBS 305. The October 1985 and 1987 cruise periods did not show this transport.

Comparative features of our 3 autumn and 2 spring sampling periods are given in Table 1 , within the context of historical data for both the fall and spring periods at SCBS 305. Our 3 October sampling periods bracketed the median values of the September to November historical data for photic depth, nitracline depth, POC and PON concentrations, and the fraction of the photic zone containing the nitracline. Integral primary production values through the photic zone for our October periods were on the high end of the historical values for autumn, while integrated chlorophyll concentrations were on the low end of the historical values. The integrated chlorophyll concentration for October 1986 was the lowest recorded. October profiles (Fig. 3) typically showed that POC and chlorophyll concentrations, as well as new production rates and POC residence times, peaked near the top of the nitracline, regardless of nitracline depth or its relation to the bottom of the mixed layer or to the photic depth. Primary production maxima bore no consistent relationship to nitracline depths, however. In October 1986 (Fig. 3) the productivity peak was associated with the top of the nitracline. In contrast, the productivity peaks for October 1985 and 1987 (not shown) were well above nitracline depth. Although integral primary production values through the photic depth during the 3 October periods were similar, the fractions of production above and below the nitracline were different (Table 2). Most of the total production occurred above the nitracline in October 1985 (87.8\%) and 1987 (83.9\%), but in October 1986 production below the nitracline exceeded that above it. These differences appeared to be a consequence of the relative position of the nitracline within the photic zone. In October 1985 and 1987, respectively, $75 \%$ and $89 \%$ of the photic zone was above the nitracline. During the October 1986 cruise, however, only $41 \%$ of the photic zone was above the nitracline. Whether this was in some way connected to the anomalous flow pattern during the October 1986 cruise is unknown

New production was higher above the nitracline in October 1985 but higher within the nitracline in October 1986 and 1987 (Table 2). Higher new production above the nitracline likely was the result of entrainment of nanomolar levels of nitrate into nearsurface waters via small wind events (Eppley \& Renger 1988), and probably was an ephemeral condition in October 1985. New production as a percentage of total primary production was approximately the same over 

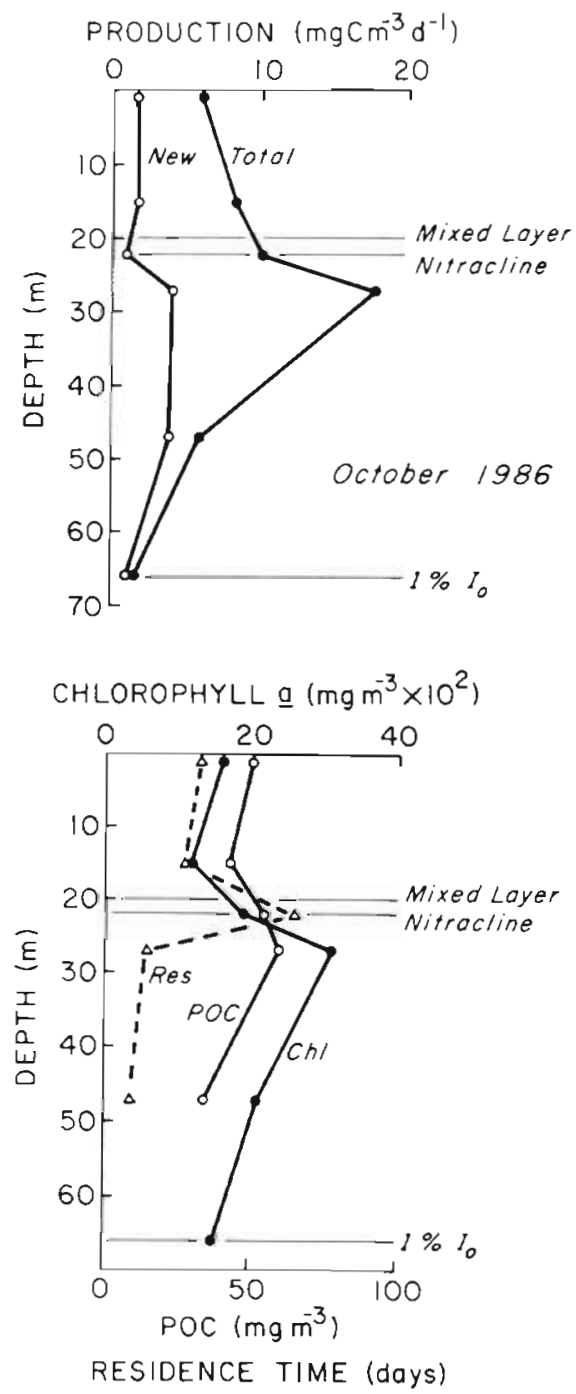

Fig. 3. Profiles of primary and new production, chlorophyll, POC and particle residence time, all relative to the depths of the mixed layer, top of the nitracline and photic zone in October 1986 at Stn SCBS 305

the photic depth for the 3 October periods, and for April and May as well (Table 2), even though the fraction of the photic zone containing nitrate varied from 25 to $59 \%$ (Table 1). As expected, the percentages of new production above the nitracline were low while those within the nitracline were high (Table 2), but the ratios of above-nitracline to within-nitracline percentages bore no relationship to depth of the photic zone or to the fraction of the photic zone containing nitrate.

The primary production profile for April 1987 (Fig. 4b) was more like the October 1986 profile than the May 1986 profile (Fig. 4a). April production was $521 \mathrm{mg} \mathrm{C} \mathrm{m}^{-2} \mathrm{~d}^{-1}$ over a $51 \mathrm{~m}$ photic depth, less than half the value in May over a $39 \mathrm{~m}$ photic depth (Table 1). No mixed layer had developed in the April
Table 2. Integral primary production (PP) and new production (NP) through 3 depth horizons, all as $\mathrm{mg} \mathrm{C} \mathrm{m} \mathrm{m}^{-2} \mathrm{~d}^{-1}$. Percentage comparisons are also given. The 3 depth horizons are the sea surface to the top of the nitracline, within the nitracline to the photic depth, and the sea surface to the photic depth

\begin{tabular}{lrrrc|}
\hline $\begin{array}{l}\text { Cruise } \\
\text { Date }\end{array}$ & $\begin{array}{c}\text { Depth range } \\
(\mathrm{m})\end{array}$ & PP & NP & $\frac{\text { NP }}{\mathrm{PP}} \times 100$ \\
\hline & $0-36$ & 466 & 78 & 16.7 \\
CaBS-1 & $36-48$ & 65 & 33 & 50.8 \\
Oct 1985 & $0-48$ & 531 & 111 & 20.9 \\
& $0-27$ & 244 & 14 & 5.7 \\
CaBS-4 & $27-66$ & 313 & 102 & 32.6 \\
Oct 1986 & $0-66$ & 557 & 116 & 20.8 \\
& $0-50$ & 532 & 21 & 4.0 \\
CaBS-7 & $50-72$ & 102 & 83 & 81.4 \\
Oct 1987 & $0-72$ & 634 & 104 & 16.4 \\
& $0-16$ & 634 & 39 & 6.2 \\
CaBS-3 & $16-39$ & 620 & 149 & 24.0 \\
May 1986 & $0-39$ & 1254 & 188 & 15.0 \\
& $0-35$ & 389 & 43 & 11.1 \\
CaBS-5 & $35-51$ & 132 & 64 & 48.5 \\
Apr 1987 & $0-51$ & 521 & 107 & 20.5 \\
\hline
\end{tabular}

water column, although the top of the nitracline was set at $35 \mathrm{~m}$. Peaks in new production were found at or below the nitracline but still in the photic zone during both months, as expected. Integral chlorophyll concentrations in April were also much lower than in May, although they were somewhat larger than those in October (Table 1). The peak POC concentration in May coincided with the chlorophyll maximum (Fig. 4a). This peak was 7 times greater than the POC maximum in October 1986 (Fig. 3). Conversely, the April POC profile did not mirror the chlorophyll profile (Fig. 4b), and the POC maximum was only somewhat greater than that in October 1986. The profile for POC residence time in April was erratic above the nitracline (Fig. 4b), with the $18 \mathrm{~m}$ value appearing to be anomalous. In contrast, the peak in the profile of POC residence time in May (Fig. 4a) was between the mixed layer depth and the top of the nitracline, similar to the observed patterns for the 3 October cruises (1986 in Fig. 3; others not shown).

Historical data at SCBS 305 during March to May showed that the April 1987 photic zone approached the maximum historical depth (Table 1). Low integral primary production and chlorophyll concentrations in April 1987 relative to the March-May medians suggested that spring upwelling had not yet occurred. However, the May 1986 data indicated that upwelling had occurred at that time. Both the primary production rate and chlorophyll concentration in May were the highest recorded at SCBS 305 in spring (Table 1). 

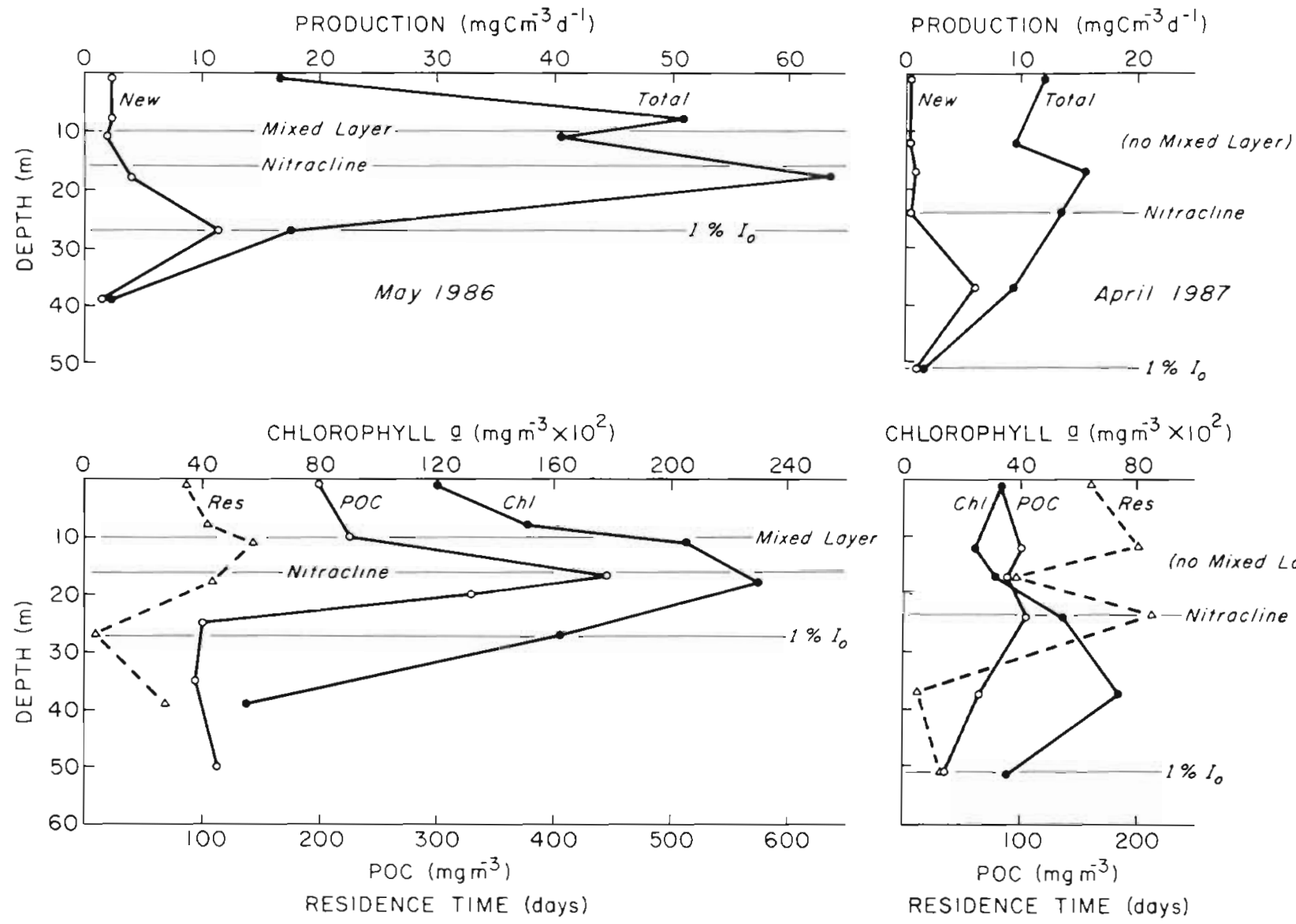

CHLOROPHYLL $\underline{a}\left(\mathrm{mg} \mathrm{m}^{-3} \times 10^{2}\right)$

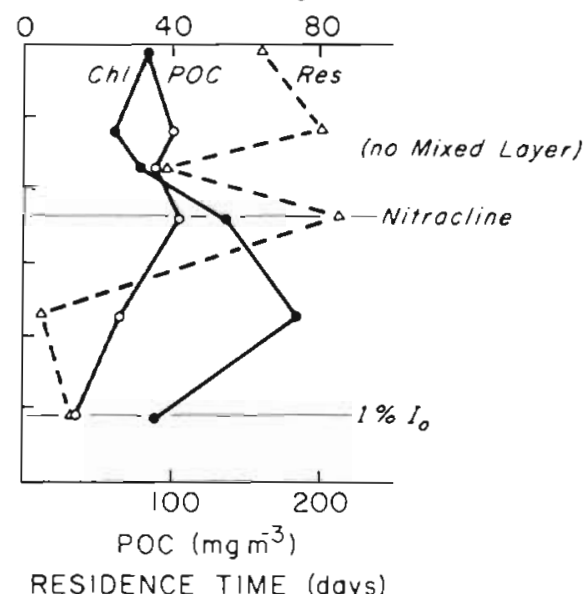

a

b

Fig. 4. Same as Fig. 3, (a) May 1986, (b) April 1987. Note scale changes for chlorophyll, POC and residence time, relative to Fig. 3

\section{Bacteria and microflagellates}

While bacterial biomass (as carbon) over the complete photic zone was only about $50 \%$ higher in May than in October 1986, cumulative C flux into bacteria in May was 16 times that in October (Table 3). The carbon intake above the top of the nitracline in May (0 to $16 \mathrm{~m}$ ) was almost twice that within the nitracline (16 to $39 \mathrm{~m}$ ) even though biomass above the nitracline was only about $20 \%$ higher than that within the nitracline. Turnover time of the bacterial biomass throughout the photic zone in May was $6.2 \mathrm{~d}$, similar to the general range reported in the literature from the SCBS area for photic zone waters. The turnover time in the October 1986 photic zone, however, was exceptionally long for coastal surface waters, perhaps as a consequence of the transport of material from the San Pedro shelf region during the October 1986 cruise period. Microflagellate carbon appeared to be low for nearshore waters, both in May and October (Table 3).

\section{Particulate flux}

Measured particulate carbon fluxes (PCF) during the 5 deployment periods ranged from 184 to $542 \mathrm{mg} \mathrm{m}^{-2}$ $\mathrm{d}^{-1}$ (Table 4). Particulate nitrogen fluxes (PNF) varied from 14.8 to $49.4 \mathrm{mg} \mathrm{m}^{-2} \mathrm{~d}^{-1}$. The highest carbon and nitrogen fluxes occurred during the October 1986 deployment while the lowest rates were measured in October 1985 (carbon) and October 1987 (nitrogen). Spring (May 1986 and April 1987) values were intermediate; hence, there was no obvious seasonal trend in the results. However, during the October 1986 deployment period, lateral advection of particles from the San Pedro shelf region was suggested by transmissometer surveys and current data (Hickey pers. comm.). This could explain why carbon flux rates at SCBS 305 in October 1986 were not comparable to flux rates in the other October periods. If data from this period are ignored, flux estimates from the spring cruises (May and April) exceeded those in the remaining October 
Table 3. Bacterial carbon, cumulative microflagellate carbon, and cumulative carbon flux into bacteria in the photic zone at SCBS 305 in May and October 1986. Net bacterial mass turnover time was computed. Data by depth horizon within the photic zone was available for May 1986 only

\begin{tabular}{|c|c|c|c|c|c|}
\hline $\begin{array}{l}\text { Cruise } \\
\text { Date }\end{array}$ & $\begin{array}{l}\text { Depth range } \\
\qquad(\mathrm{m})\end{array}$ & $\begin{array}{l}\text { Bacterial carbon } \\
\quad\left(\mathrm{mg} \mathrm{C} \mathrm{m} \mathrm{m}^{-2}\right)\end{array}$ & $\begin{array}{c}\text { Microflagellate } \\
\text { carbon } \\
\left(\mathrm{mg} \mathrm{C} \mathrm{m} \mathrm{Cm}^{-2}\right)\end{array}$ & $\begin{array}{l}\text { Cumulative carbon } \\
\text { flux into bacteria } \\
\left(\mathrm{mg} \mathrm{C} \mathrm{m}^{-2} \mathrm{~d}^{-1}\right)\end{array}$ & $\begin{array}{l}\text { Bacterial mass } \\
\text { turnover time } \\
\text { (d) }\end{array}$ \\
\hline CaBS-3 & $0-16$ & 1179 & - & 410 & 5.8 \\
\hline \multirow[t]{2}{*}{ May 1986} & $16-39$ & 986 & & 287 & 6.8 \\
\hline & $0-39$ & 2165 & 14 & 697 & 6.2 \\
\hline $\begin{array}{l}\text { CaBS-4 } \\
\text { October } 1986\end{array}$ & $0-66$ & 1450 & 7 & 43 & 67.4 \\
\hline
\end{tabular}

Table 4. Flux rates of particulate carbon (PCF) and nitrogen (PNF) from material collected in sediment traps overlying the Santa Monica Basin (SCBS 305). Flux rates $\left(\mathrm{mg} \mathrm{m}^{-2} \mathrm{~d}^{-1}\right.$ ) are the means of rates estimated for individual traps at 90 and $100 \mathrm{~m}$, except for triplicate traps at $100 \mathrm{~m}$ in October 1987 . New production estimates compare rates determined from traps and from nitrate uptake experiments. Both were measured as nitrogen but are expressed here in carbon equivaients ( $\mathrm{mg} \mathrm{C} \mathrm{m}{ }^{-2} \mathrm{~d}^{-1}$ ) assuming a Redfield C : N ratio of 5.7 by weight. Residence times (d) of particulate carbon (PC) and nitrogen (PN) are photic zone averages determined from flux rates and carbon and nitrogen standing stocks from Table 1

\begin{tabular}{|c|c|c|c|c|c|c|}
\hline \multirow{2}{*}{ Cruise } & \multicolumn{2}{|c|}{ Flux rate } & \multicolumn{2}{|c|}{ New production } & \multicolumn{2}{|c|}{ Residence time } \\
\hline & PCF & PNF & Trap flux & $\mathrm{NO}_{3}^{-}$uptake & $\mathrm{PC}$ & PN \\
\hline October 1985 & 184 & 17.2 & 98 & 111 & 18.3 & 33.7 \\
\hline October 1986 & 542 & 49.4 & 282 & 116 & 4.5 & 10.4 \\
\hline October 1987 & 241 & 14.8 & 84 & 104 & 15.9 & 47.4 \\
\hline May 1986 & 259 & 28.0 & 160 & 188 & 33.9 & 55.2 \\
\hline April 1987 & 442 & 33.8 & 193 & 141 & 11.4 & 21.2 \\
\hline
\end{tabular}

cruises by about a factor of 2 on average (Table 4). Higher flux rates in the springtime are a reasonable generalization given the higher suspended particle concentrations and primary production rates (Table 1) and the greater biomass of macrozooplankton grazers (Table 6 , below) in the springtime relative to autumn.

The uptake of nitrate by phytoplankton in the photic zone and the sinking flux of particulate nitrogen from the photic zone are alternative methods of estimating new production. Because these 2 rates are controlled by different mechanisms, they can vary independently of one another in the short term. However, in the absence of advective bias, nitrate uptake and PNF should be approximately in balance over longer time periods. In the present data set we converted both nitrate uptake and PNF to particulate carbon terms by multiplying by 5.7 . The carbon-based uptake rates exceeded the carbon-based flux estimates during the October 1985, October 1987, and May 1986 cruises, but the reverse was true in October 1986 and April 1987 (Table 4). Assuming that flux rates from October 1986 were biased by lateral advection, as suggested above, mean new production estimates from sediment traps (134 $\mathrm{mg} \mathrm{C} \mathrm{m} \mathrm{m}^{-2} \mathrm{~d}^{-1}$ ) and from nitrate-uptake experiments (136 $\mathrm{mg} \mathrm{C} \mathrm{m}^{-2} \mathrm{~d}^{-1}$ ) were in excellent agreement for the remaining 4 cruises. Agreement was also good when just the means of the 2 October periods or the means of the 2 spring periods were compared.

Estimates of new production in terms of carbon, inferred from nitrate uptake or particulate nitrogen flux, were on the order of half the particulate carbon flux rates ( $\mathrm{PCF}$ ) measured in traps (Table 4 ). Given the likelihood of significant wind-borne and other detrital carbon inputs at our study site, the nitrogen data were presumed to provide a more reasonable basis for assessing the fate of in situ primary production. Nonetheless, the $\mathrm{C}: \mathrm{N}$ ratio of trap material commonly exceeded the $\mathrm{C}: \mathrm{N}$ ratio of bulk suspended particulate matter in the overlying water column, at least partly because planktonic consumers solubilized and assimilated nitrogen from food with a higher efficiency than carbon. The outcome of this fractionation was a low body $\mathrm{C}: \mathrm{N}$ ratio in zooplankton relative to their food, and subsequently a high $C: N$ ratio in the released fecal matter (LeBorgne 1982, Small et al. 1983, Landry et al. 1984). Such a mechanism appeared to be in operation in Santa Monica Basin (Table 5), although the $\mathrm{C}: \mathrm{N}$ ratios in fresh fecal pellets were measured on only 2 cruises.

The mean residence times of particulate carbon and nitrogen in the photic zone were determined from flux rates in sediment traps and depth-integrated standing stocks from Table 1. The enrichment of carbon in the 
Table 5. Carbon: nitrogen weight ratios (mean $\pm 1 \mathrm{SD}$ ) in bulk suspended particulate matter, trap material, macrozooplankton bodies, and fresh fecal pellets of macrozooplankton in the photic zone in Santa Monica Basin. nd: no data

\begin{tabular}{|lcccc}
\hline Date & Suspended particles & Trap material & Zooplankton bodies & Fecal pellets \\
\hline Oct 1985 & $7.8 \pm 2.7$ & $9.6 \pm 3.1$ & $3.9 \pm 0.1$ & nd \\
Oct 1986 & $4.9 \pm 0.4$ & $7.3 \pm 2.2$ & $3.8 \pm 0.1$ & nd \\
Oct 1987 & $5.9 \pm 1.2$ & $12.0^{\mathrm{a}}$ & $4.0 \pm 0.2$ & $7.0 \pm 0.2$ \\
May 1986 & $4.9 \pm 0.8$ & $9.3 \pm 1.1$ & $4.4 \pm 0.3$ & nd \\
Apr 1987 & $6.9 \pm 0.9$ & $9.8 \pm 1.6$ & $4.2 \pm 0.3$ & $7.5 \pm 0.2$ \\
a Based on 2 ratios at $50 \mathrm{~m}$ only & & & \\
\hline
\end{tabular}

C:N ratio of sediment trap material relative to suspended particulate matter in the photic zone (Table 5) resulted in $\mathrm{PC}$ residence time estimates about half those of PN (Table 4). Relatively short residence times (4.5 d for PC; $10.4 \mathrm{~d}$ for PN) were computed for October 1986, while the May 1986 cruise yielded the longest residence time estimates (33.9 d for PC, $55.2 \mathrm{~d}$ for $\mathrm{PN}$ ). Excluding the October 1986 data, $\mathrm{PC}$ and $\mathrm{PN}$ residence times averaged about $20 \mathrm{~d}$ and $39 \mathrm{~d}$, respectively, with no apparent seasonal trend; i.e. higher standing stocks were generally countered by higher flux rates.

\section{Macrozooplankton biomass and particle removal}

Representative night-time and daytime biomass distributions of the macrozooplankton, by size group and in total, are shown in Figs. 5 and 6. Peak zooplankton biomass coincided with, or was just below, the chlorophyll maximum (Figs. 3 and 4 ) at all times except during the night in April 1987. It is immediately apparent that the total biomasses in April 1987 and May 1986 (Fig. 6 and Table 6) far exceeded those in the 3 October periods (Fig. 5 and Table 6); hence, the springtime populations in the photic zone represented a formidable pathway through which primary production could be transformed into fecal material. The high April biomass was not balanced by a correspondingly high level of potential food supply; that is, although chlorophyll and POC concentrations were close to doubling the October concentrations, both primary and new production were about the same in April and October (Table 2). In May 1987, however, high levels of primary biomass and production co-occurred with high zooplankton biomass. The bulk of the night-time zooplankton biomass during both April and May was composed of larger (mainly 1000-2000 $\mu \mathrm{m}$ ) animals (Fig. 6). In October the biomass of the smallest size group $(200-500 \mu \mathrm{m})$ usually slightly exceeded those of the other size groups at night (Fig. 5). In. October the daytime concentrations were less than at night, as expected, but the disparity between night and day was
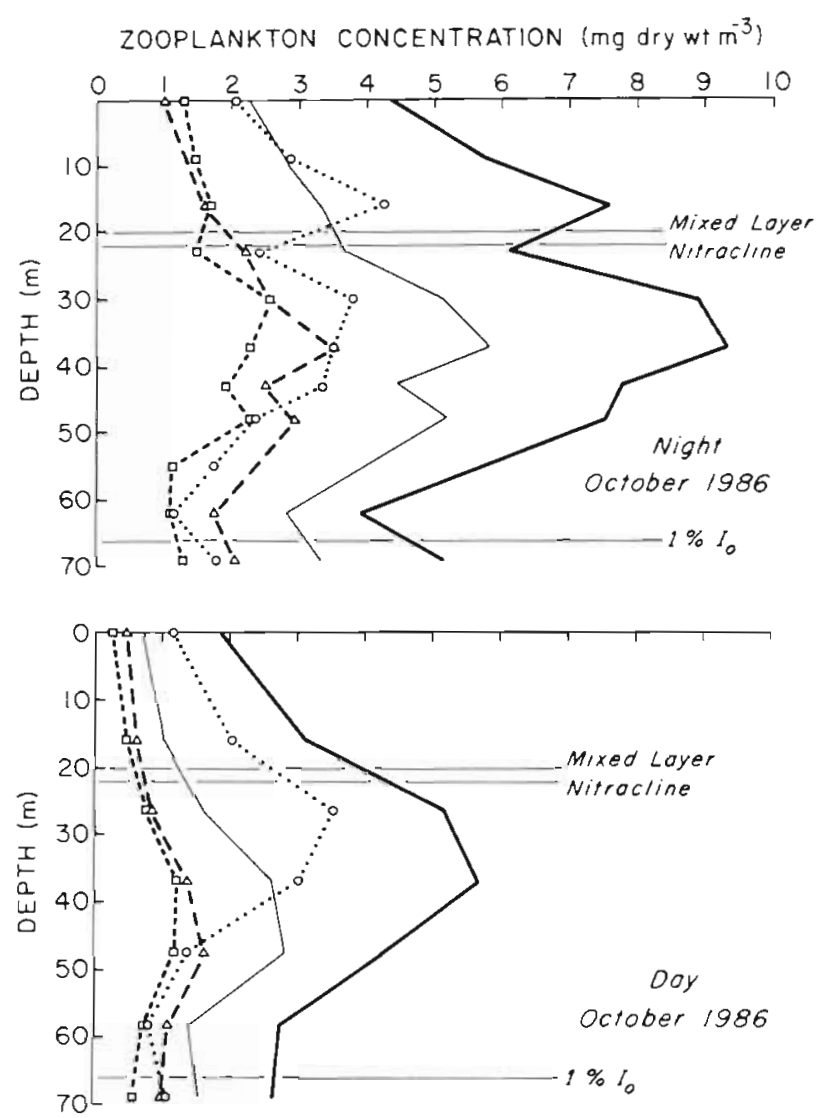

Fig. 5. Zooplankton biomass profiles for day and night periods in October 1986 in the vicinity of Stn SCBS 305, for size classes

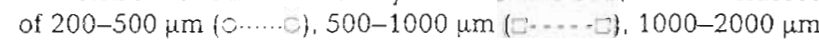
$(\triangle---\Delta), 500-2000 \mu \mathrm{m} \mathrm{( \longrightarrow )}$, and $200-2000 \mu \mathrm{m} \mathrm{( \longrightarrow )}$

not nearly as extreme as in spring (especially April 1987).

Fecal carbon production was dominated by the 200-500 $\mu \mathrm{m}$ size group in autumn throughout the photic zone, as there were large differences between the rates of the 200-2000 and 500-2000 $\mu \mathrm{m}$ size groups in October (Table 6). In October 1985 and 1987, most fecal carbon production took place above the nitracline, whereas in October 1986 most occurred below the 

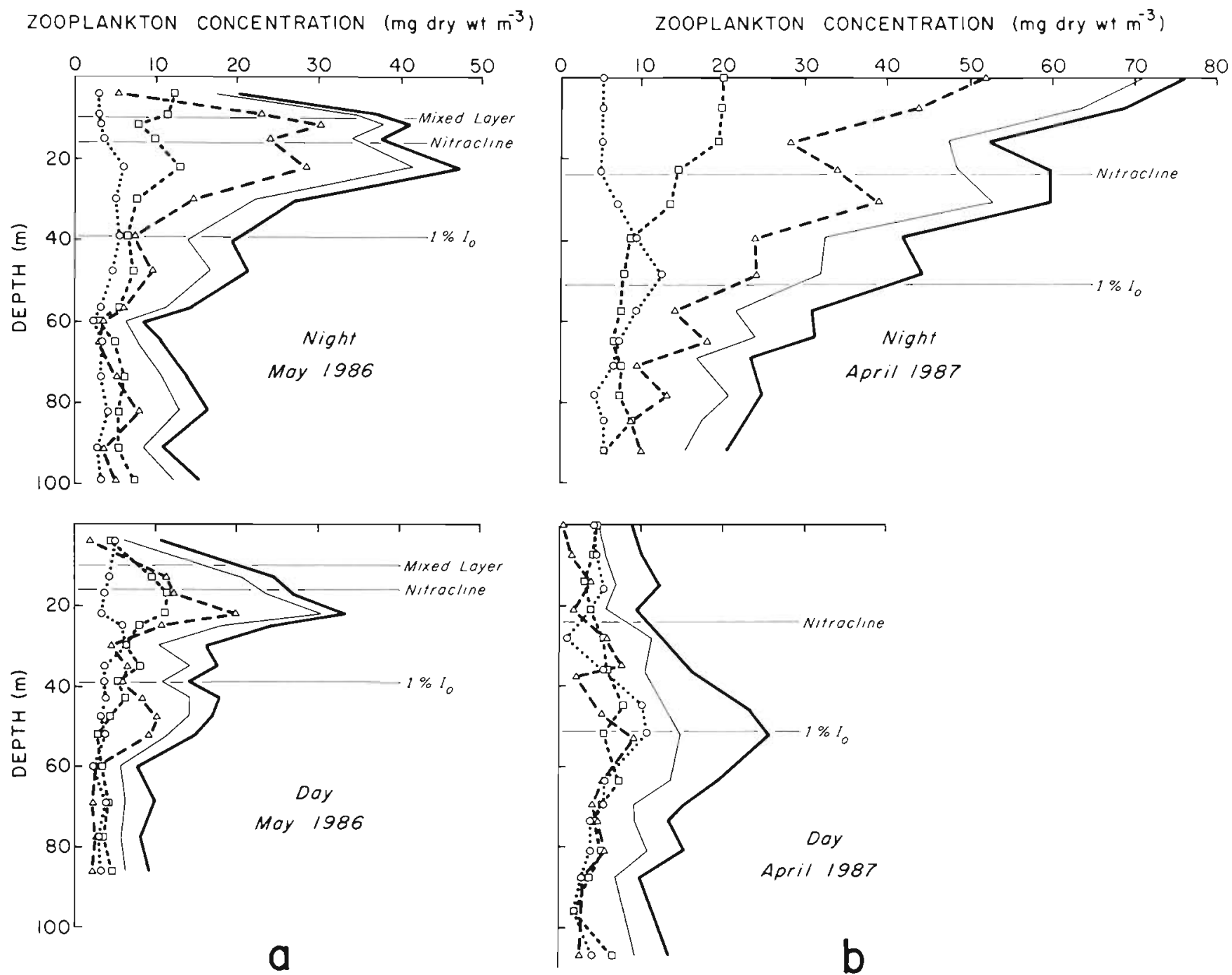

Fig. 6. Same as Fig. 5, (a) May 1986, (b) April 1987. Note scale changes relative to Fig. 5

nitracline. These distributions were similar to those of primary production during the 3 October periods (Table 2), but had no clear relationship with new production (Table 2). Such distributions suggested that, even if a significant fraction of suspended particulate matter in October was consumed by zooplankton, most of the egested material was in the form of small particulate debris rather than large, sinking pellets.

In May 1986, fecal carbon production was more significant within the nitracline, and the larger size classes of zooplankton accounted for a significant fraction of total fecal production (Table 6). In addition, daylight fecal production was as great or greater than nighttime production (not shown). These distributions differed from the pattern of primary production, but they conformed to the pattern of new production in the photic zone (Table 2). Fecal production rates in April 1987 were generally greater than those in May 1986, with the larger animal size classes again representing a significant fraction of total fecal carbon production. Unlike May, however, pellet production above the nitracline in April was more significant than that within the nitracline (Table 6), and night-time pellet production exceeded daylight production throughout the photic zone (not shown). April fecal carbon production thus had some of the elements of the May period and some of the October period.

Because the zooplankton community in Santa Monica Basin was treated as principally a herbivorous assemblage of grazers, fecal carbon production rates could be compared to rates of primary and new production. Fecal carbon production rates by 500-2000 $\mu \mathrm{m}$ animals, as fractions of both primary and new production over the full photic zone, were similar for the October periods (Table 7). The same was true for the 200-2000 $\mu \mathrm{m}$ size group, except that, as expected, fractions were larger than for the 500-2000 um group. The fecal production rate for the full zooplankton size 
Table 6. Night (N) and day (D) zooplankton biomass $\left(\mathrm{mg} \mathrm{C} \mathrm{m}{ }^{-2}\right)$, plus daily fecal carbon production $\left[\mathrm{mg} \mathrm{C}^{-2}(24 \mathrm{~h})^{-1}\right]$ above the nitracline, within the nitracline to the photic depth $\left(1 \% \mathrm{I}_{0}\right)$, and from the surface to the photic depth for all zooplankton size classes combined $(200-2000 \mu \mathrm{m})$ and for the 2 largest size classes combined $(500-2000 \mu \mathrm{m})$

\begin{tabular}{|c|c|c|c|c|c|c|c|}
\hline \multirow[t]{3}{*}{ Date } & \multirow{3}{*}{$\begin{array}{l}\text { Depth range } \\
(\mathrm{m})\end{array}$} & \multicolumn{3}{|c|}{$500-2000 \mu \mathrm{m}$} & \multicolumn{3}{|c|}{$200-2000 \mu \mathrm{m}$} \\
\hline & & & & Fecal & & & Fecal \\
\hline & & $\mathrm{N}$ & D & production & $\mathrm{N}$ & D & production \\
\hline \multirow{3}{*}{$\begin{array}{l}\text { Oct } 1985 \\
(11 \mathrm{~h} \mathrm{D}, 13 \mathrm{~h} \mathrm{~N})\end{array}$} & $0-36$ & 52.9 & 6.4 & 2.53 & 99.8 & 9.2 & 35.71 \\
\hline & $36-48$ & 17.0 & 4.2 & 0.85 & 30.4 & 6.3 & 11.09 \\
\hline & $0-48$ & 69.9 & 10.6 & 3.38 & 130.2 & 15.5 & 46.80 \\
\hline \multirow{3}{*}{$\begin{array}{l}\text { Oct } 1986 \\
(11 \text { h D, } 13 \text { h N })\end{array}$} & $0-27$ & 30.9 & 10.7 & 1.13 & 63.4 & 34.5 & 27.55 \\
\hline & $27-66$ & 70.2 & 31.5 & 2.85 & 104.9 & 61.4 & 33.65 \\
\hline & $0-66$ & 101.0 & 42.2 & 3.98 & 168.3 & 95.9 & 61.20 \\
\hline \multirow{3}{*}{$\begin{array}{l}\text { Oct } 1987 \\
(11 \text { h D, } 13 \text { h N) }\end{array}$} & $0-50$ & 61.0 & 13.5 & 3.43 & 98.1 & 31.5 & 30.53 \\
\hline & $50-72$ & 22.6 & 8.5 & 0.92 & 33.4 & 18.9 & 7.99 \\
\hline & $0-72$ & 83.6 & 22.0 & 4.35 & 131.5 & 50.4 & 38.52 \\
\hline \multirow{3}{*}{$\begin{array}{l}\text { May } 1986 \\
(14 \mathrm{~h} \mathrm{D}, 10 \mathrm{~h} \mathrm{~N})\end{array}$} & $0-16$ & 171.6 & 81.4 & 15.59 & 189.2 & 105.1 & 39.17 \\
\hline & $16-39$ & 264.2 & 169.6 & 25.70 & 313.5 & 210.1 & 68.91 \\
\hline & $0-39$ & 435.8 & 251.0 & 41.29 & 502.7 & 315.2 & 108.08 \\
\hline \multirow{3}{*}{$\begin{array}{l}\text { Apr } 1987 \\
(13 h D, 11 h N)\end{array}$} & $0-35$ & 735.6 & 103.1 & 41.30 & 804.7 & 151.8 & 106.17 \\
\hline & $35-51$ & 197.5 & 80.9 & 14.66 & 254.8 & 133.2 & 75.73 \\
\hline & $0-51$ & 933.1 & 184.0 & 55.96 & 1059.5 & 285.0 & 181.90 \\
\hline
\end{tabular}

Table 7. Daily fecal carbon production (FCP) by 500-2000 $\mu \mathrm{m}$ and 200-2000 $\mu \mathrm{m}$ zooplankton through the photic zone, as fractions of primary production (PP), new production by nitrate uptake (NP), estimated particulate organic flux to balance $N P$ [5.7 $\times$ particulate nitrogen flux (PNF)], and measured particulate carbon flux (PCF)

\begin{tabular}{|lcccccccc|}
\hline Date & \multicolumn{1}{c}{$500-2000 \mu \mathrm{m}$} & & \multicolumn{2}{c}{$200-2000 \mu \mathrm{m}$} \\
& $\frac{F C P}{\mathrm{PP}}$ & $\frac{\mathrm{FCP}}{\mathrm{NP}}$ & $\frac{\mathrm{FCP}}{5.7 \mathrm{PNF}}$ & $\frac{\mathrm{FCP}}{\mathrm{PCF}}$ & $\frac{\mathrm{FCP}}{\mathrm{PP}}$ & $\frac{\mathrm{FCP}}{\mathrm{NP}}$ & $\frac{\mathrm{FCP}}{5.7 \mathrm{PNF}}$ & $\frac{\mathrm{FCP}}{\mathrm{PCF}}$ \\
\hline Oct 1985 & 0.01 & 0.03 & 0.04 & 0.01 & 0.09 & 0.42 & 0.48 & 0.14 \\
Oct 1986 & 0.01 & 0.03 & 0.01 & 0.01 & 0.11 & 0.53 & 0.22 & 0.10 \\
Oct 1987 & 0.01 & 0.04 & 0.05 & 0.02 & 0.06 & 0.37 & 0.46 & 0.16 \\
May 1986 & 0.03 & 0.22 & 0.26 & 0.13 & 0.09 & 0.58 & 0.68 & 0.34 \\
Apr 1987 & 0.11 & 0.52 & 0.29 & 0.09 & 0.35 & 1.70 & 0.94 & 0.30 \\
\hline
\end{tabular}

range (200-2000 $\mu \mathrm{m})$ in May 1986, as a percentage of both primary and new production, was comparable to October percentages, although the percentage contribution from the larger size fractions $(500-2000 \mu \mathrm{m})$ was much greater in May. It was during April 1987 that the role of macrozooplankton was really significant. Fully $35 \%$ of the primary production was estimated to have passed through macrozooplankton guts, of which $11 \%$ was transformed by animals greater than $500 \mu \mathrm{m}$ (Table 7). The macrozooplankton population accounted for more than the new production rate estimated from nitrate uptake $(170 \%)$, of which $52 \%$ was by the 500-2000 $\mu \mathrm{m}$ size fraction

Fecal carbon production rate by $500-2000 \mu \mathrm{m}$ animals represented a small fraction of the estimated carbon flux needed to balance new production in the 3 October periods; i.e. the ratio of fecal carbon produc- tion to $5.7 \times$ PN flux was 1 to $5 \%$, with the October 1986 percentage the lowest (Table 7). When the complete size range of zooplankton (200-2000 um) was considered, the contribution of fecal material to $5.7 \times$ PN flux was about half those for the other 2 October periods $(22$ versus ca $47 \%)$. The low estimate for October 1986 may be the result of the lateral transport effect, which confounds the interpretation of new production estimates from sediment traps and nitrate uptake (Table 4). In April 1987,94\% of the estimated carbon flux required to balance new production was passed through zooplankton (Table 7). This percentage was still lower than that computed by FCP/NP for all zooplankton (170\%), a disparity brought about by the difference between new production calculated by nitrate uptake and by trap flux in April 1987 (Table 4).

Fecal carbon production rates for the $200-2000 \mu \mathrm{m}$ 
size range of zooplankton, computed as fractions of total PC flux (PCF), were similar and fairly low (10 to $16 \%$ ) for the 3 October periods (Table 7 ). In spring, fecal production rates were relatively high fractions of PCF, with little difference between May 1986 (34\%) and April 1987 (30\%). The spring season is thus at least twice as significant as autumn in terms of the role of macrozooplankton in transforming the upper-water small-particle field in Santa Monica Basin.

\section{DISCUSSION}

\section{Temporal comparisons}

Chlorophyll, primary production, new production measured by nitrate uptake, and the ratio of new to total production in the photic zone during the 5 cruise periods, were seasonally consistent and in line with available historical measurements in Santa Monica Basin. The October 1986 data were somewhat anomalous, however. For example, both PC and PN flux rates out of the upper waters during the October 1986 period were more than double those of the other 2 October periods, so that trap-derived new production estimates were substantially higher and particulate residence times substantially shorter in October 1986 than during the other 2 October cruises (Table 6). The biomass and fecal pellet production by small zooplankton were also higher in October 1986 compared to October 1985 and 1987, with most of the biomass and pellet production occurring below the top of the nitracline in 1986 (Table 6). The upper water column in October 1986 thus appeared not to be near steady state, and in this sense was unique among the other cruises, including the 2 spring cruises.

With regard to the 2 spring cruises, April 1987 apparently was a transitional period with some characteristics common to autumn periods (depths of the photic zone and top of the nitracline, and integrated primary production rates, for example) and some common to May 1986 (PC flux rates and N-based new production rates, for example). The May 1986 period had all the characteristics of summer in Santa Monica Basin, with a shallow photic depth and nitracline yet high integral primary and new poduction. Perhaps the major similarities between the April 1987 and May 1986 periods were the high biomasses and fecal carbon production rates of the macrozooplankton in the photic zone (Table 6). These measurements were several times larger than comparable measurements during any of the October periods. Fecal carbon production rates in the spring months (particularly April 1987) represented significant fractions of new production rates and particulate carbon fluxes (Table 7 ).

\section{Particle flux and residence time}

Excluding the October 1986 date, particulate carbon and nitrogen residence times in the photic zone averaged about $20 \mathrm{~d}$ and $39 \mathrm{~d}$, respectively, with no apparent seasonality. Eppley et al. (1983) earlier had estimated residence times of 3 to $100 \mathrm{~d}$ (median about $30 \mathrm{~d}$ ) from new production estimates and standing stocks of particles in the Southern California Bight. They also noted a significant disparity between nitrogen-based (new production) and carbon-based (trap flux) estimates of residence time. In order to obtain another, independent estimate of particle residence time in Santa Monica Basin, we looked toward ${ }^{234}$ Thorium, an isotope which has been measured in both particulate and dissolved phases in the water column and in sediment trap material in the California Current (Coale \& Bruland 1985) and in Santa Monica Basin (Huh \& Beasley 1987). The October 1985 data of Huh \& Beasley (1987) were almost concurrent with our October 1985 data. However Huh \& Beasley (1987) estimated that the residence time of ${ }^{234}$ Th already in particulate form in the photic zone of Santa Monica Basin was 4 to $7 \mathrm{~d}$ in October 1985, clearly shorter than our PC or PN residence times for October 1985 and at the short-time end of the range estimated by Eppley et al. (1983) in the Southern California Bight. Huh \& Beasley (1987) hypothesized that the major carrier phase(s) of particulate ${ }^{234} \mathrm{Th}$, unlike particulate $\mathrm{C}$ or $\mathrm{N}$, must have undergone little remineralization in the photic zone, a point also brought out by Coale $\&$ Bruland (1985) who determined residence times from 2.4 to $18 \mathrm{~d}$ for particulate ${ }^{234} \mathrm{Th}$ at various stations in the California Current. The above authors suggested that the short particulate ${ }^{234} \mathrm{Th}$ residence times might have indicated effective zooplankton grazing on the suspended particles followed by the conversion into rapidly sinking fecal pellets.

Clearly particulate ${ }^{234} \mathrm{Th}$ residence times do not reflect $\mathrm{PC}$ or $\mathrm{PN}$ residence.times. However, the rate of adsorption of dissolved ${ }^{234} \mathrm{Th}$ onto particles yielded a residence time of 21 to 28 d during October 1985 (Huh $\&$ Beasley 1987). This 'dissolved residence time', coupled with the residence time of 4 to $7 \mathrm{~d}$ for particulate ${ }^{234} \mathrm{Th}$ in the photic zone, yielded an overall residence time of 25 to $35 \mathrm{~d}$. If new production was in some way tied to the scavenging of dissolved ${ }^{234} \mathrm{Th}$ and its ultimate loss from the photic zone as particulate ${ }^{234} \mathrm{Th}$, then the overall residence time of ${ }^{234} \mathrm{Th}$ might be a reasonable measure of new production. We examined this possibility for October 1985. The PON concentration in the photic zone was $579 \mathrm{mg} \mathrm{N} \mathrm{m}^{-2}$ (Table 1). This concentration divided by the overall ${ }^{234} \mathrm{Th}$ residence time ( 25 to $35 \mathrm{~d}$ ) yielded a PON export rate from the photic zone of 17 to $23 \mathrm{mg} \mathrm{N} \mathrm{m} \mathrm{m}^{-2} \mathrm{~d}^{-1}$, a flux that 
compared extremely well with the trap-derived PN flux of $17.2 \mathrm{mg} \mathrm{N} \mathrm{m} \mathrm{m}^{-2} \mathrm{~d}^{-1}$ (Table 4) and with the nitratebased new production rate of $19.5 \mathrm{mg} \mathrm{N} \mathrm{m}^{-2} \mathrm{~d}^{-1}$ (111/5.7 $=19.5$, from Table 4). The relationship needs to be tested further before its general applicability, or lack thereof, is known. However, if in fact new production is linked to the scavenging of dissolved ${ }^{234} \mathrm{Th}$ in upper waters, then either (1) macrozooplankton must consume particles equivalent to the new production and turn the non-assimilated fraction of that consumed quantity into rapidly sinking fecal pellets heavily invested with ${ }^{234} \mathrm{Th}$, or (2) ${ }^{234} \mathrm{Th}$-laced particles equivalent to new production must be quickly introduced into marine snow which rapidly settles out of the photic zone. Presumably in the latter case at least some of the particulate ${ }^{234} \mathrm{Th}$ could be concentrated rapidly in fecal matter of microheterotrophs, with this fecal matter then being carried down in marine snow aggregates. Direct sinking of minute particles containing ${ }^{234} \mathrm{Th}$ would not be rapid enough to account for the 4 to $7 \mathrm{~d}$ residence time of particulate ${ }^{234} \mathrm{Th}$ in the October 1985 photic zone.

Some insight into the potential of the herbivorous macrozooplankton populations to balance new production by producing sinking fecal matter can be obtained from Table 7 , in which fecal carbon production has been calculated as a fraction of new production in terms of carbon (i.e. fecal carbon production either as a fraction of new production by nitrate uptake or as a fraction of particulate nitrogen flux times 5.7). In autumn, for example (excluding October 1986), pellet production accounted for 37 to $48 \%$ of new production. However, most of this fecal matter likely was in the form of small particulate debris, because of the prominence of small zooplankton (200 to $500 \mu \mathrm{m}$ ) at this time of year. Pellet production by the zooplankton size group most likely to contribute directly to particle flux (the 500 to $2000 \mu \mathrm{m}$ size group) accounted for only 3 to $5 \%$ of new production in October 1985 and 1987 (Table 7). Rapidly sinking marine snow aggregates, invested with the fecal debris, probably provided the major input to the traps in autumn. Marine snow aggregates often have $\mathrm{C}: \mathrm{N}$ ratios higher than the surrounding field of smaller suspended particles (Prézelin \& Alldredge 1983, Alldredge \& Silver 1988), and thus collectively would be a good source for the trap material.

In spring the direct contribution of macrozooplankton to total carbon flux was greater than in autumn, mainly because of the increase in fecal pellet production by the larger zooplankton (Table 7). Pellet production by the 500-2000 um size group accounted for 22 to $52 \%$ of new production in April and May. If all of the fecal matter produced by the total size range of macrozooplankton (200-2000 $\mu \mathrm{m}$ ) in April and May had sunk directly into traps, all (94 to 170\%) of the trap-measured carbon flux would have first passed through zooplankton. Again, this was unlikely because of the large fecal production by small (200-500 $\mu \mathrm{m})$ zooplankton, production that probably did not contribute directly and rapidly to total carbon flux out of the photic zone. Even though not all of the upper-water fecal production sank quickly through the photic zone, the amount of suspended particulate matter transformed by zooplankton clearly was significant, and thus pointed up the often important role of macrozooplankton in particle dynamics of the photic zone.

It is common in marine environments to measure carbon-based flux rates (PCF) that are higher than nitrogen-based flux rates converted to carbon by the Redfield ratio $5.7 \times$ PNF (e.g. Knauer et al. 1979, Honjo 1980, Martin et al. 1987). Such is the case for our Santa Monica Basin results (Table 4), although our $\mathrm{C}: \mathrm{N}$ flux ratios might be slightly inflated because we did not acidify the trap material to remove inorganic PC in our short-term trap sets. It is also a fact that in plankton communities the $\mathrm{C}: \mathrm{N}$ body ratio of zooplankton is lower than that of phytoplankton and most other potential food particles (e.g. Ikeda 1974, LeBorgne 1982, Small et al. 1983). This also was true for Santa Monica Basin (Table 5). The number of times a nitrogen atom is recycled in upper waters before it is transported to depth, and the associated ratio of regenerated production to total production, must be related to the carbon excess in sinking material. We propose that this differential cycling of $C$ and $N$ is the reason (1) that an excess carbon flux is characteristic of oligotrophic and nearoligotrophic regions, and (2) that low $C: N$ ratios are maintained in the suspended matter even in nutrientdepleted photic zones. Such a mechanism would permit us to propose incipient $\mathrm{N}$-limitation of phytoplankton growth rates in such environments in spite of Redfield-like $\mathrm{C}$ : $\mathrm{N}$ ratios for the suspended particulates. Goldman et al. (1979) earlier proposed such $C: N$ ratios were evidence that phytoplankton growth rates were not $\mathrm{N}$-limited in oligotrophic ocean waters because the $\mathrm{C}: \mathrm{N}$ composition ratio of phytoplankton increases markedly when growth rate is reduced by nutrient stress. Since the $C: N$ ratio of the suspended matter in Santa Monica Basin reflects bacteria and detritus (and to a lesser extent, colorless flagellates) as well as phytoplankton, an increase in phytoplankton C.N ratio related to $\mathrm{N}$-stress could be hidden by relative increase in bacterial biomass with relatively low $C: N$ composition ratios ( $<4$; Lee \& Fuhrman 1987).

\section{Carbon and nitrogen budgets}

The measurements we have made to date allow us a first attempt at carbon and/or nitrogen budgets for the photic zone in Santa Monica Basin during autumn and 
Upper Euphotic Zone Above Nitracline $(0-16 \mathrm{~m})$
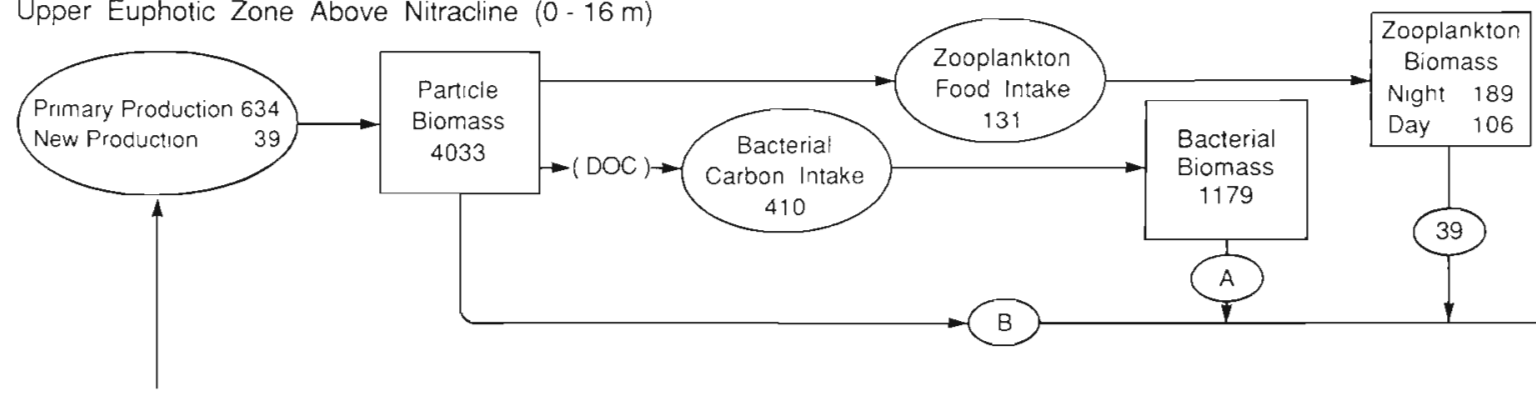

Lower Euphotic Zone Within Nitracline $(16-39 \mathrm{~m})$
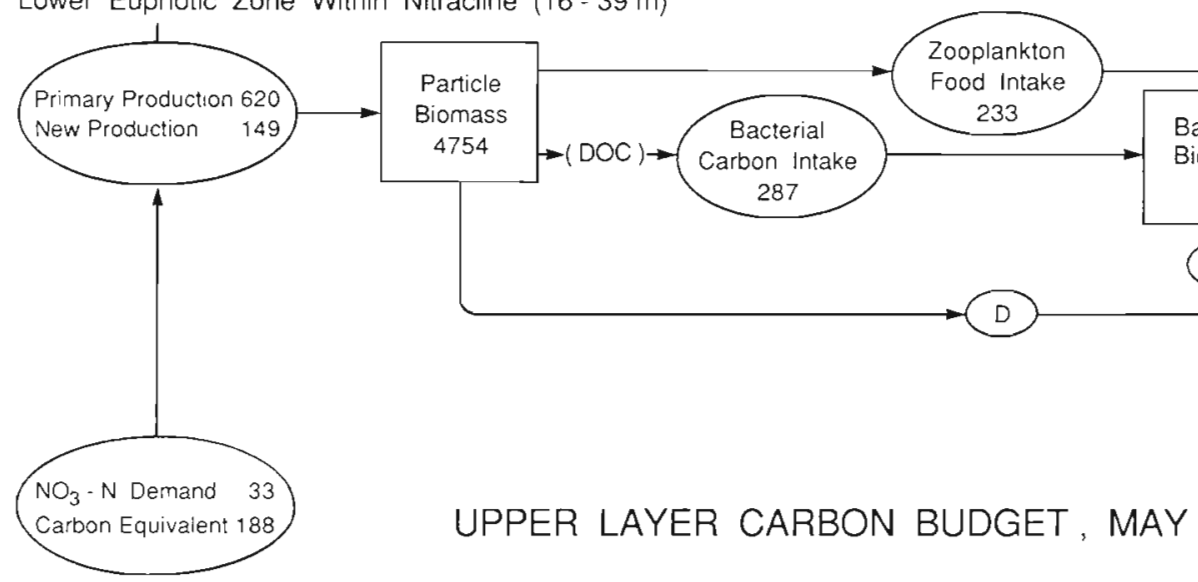

1986

Fig. 7. Carbon budget for the photic zone in May 1986. The photic zone is divided into a layer above the top of the nitracline $(0$ to $16 \mathrm{~m}$ ) and a layer within the nitracline $(16$ to $39 \mathrm{~m})$, to illustrate relationships among processes within those 2 layers. Numbers within oval symbols represent rates ( $\mathrm{mg} \mathrm{C} \mathrm{m}^{-2} \mathrm{~d}^{-1}$, except for $\mathrm{NO}_{3}^{-}-\mathrm{N}$ demand and PN particle flux which are in $\mathrm{mg} \mathrm{N}^{-2} \mathrm{~d}^{-1}$ ). Numbers within rectangles are biomasses $\left(\mathrm{mg} \mathrm{C} \mathrm{m}^{-2}\right.$ ). The numbers 39 and 69 (emanating from zooplankton biomass rectangles) are rates of fecal carbon production. Letters $A, B, C$ and $D$ are unmeasured rates. See text for further details

spring. A simplified example, in terms of carbon, is given in Fig. 7 for May 1986. The photic zone was 2layered with an upper, nutrient-depleted but light-rich layer $16 \mathrm{~m}$ deep and a nutrient-rich, light-poor layer extending to $39 \mathrm{~m}$. Most of the new production (total of $188 \mathrm{mg} \mathrm{C}^{-2} \mathrm{~d}^{-1}$, by nitrate uptake) took place in the lower photic zone where nitrate was abundant (compare new production rates of $39 \mathrm{vs} 149 \mathrm{mg} \mathrm{C} \mathrm{m}^{-2} \mathrm{~d}^{-1}$ for the upper and lower photic zone, respectively). Zooplankton biomass, food intake (estimated from a $30 \%$ 'egestion efficiency') and feces production were also greatest in the lower photic zone. The feces production (39 $\mathrm{mg} \mathrm{C} \mathrm{m}^{-2} \mathrm{~d}^{-1}$ in the upper layer, $69 \mathrm{mg} \mathrm{C}$ $\mathrm{m}^{-2} \mathrm{~d}^{-1}$ in the lower) contributed either directly or indirectly to the particle flux at $100 \mathrm{~m}$, depending upon whether fecal pellets sank directly out of the photic zone or fecal debris descended with marine snow.

Much of the particle flux in May 1986 arose from sources other than the fecal matter of herbivorous zooplankton, however. Bacterial carbon intake was estimated at $410 \mathrm{mg} \mathrm{C} \mathrm{m}^{-2} \mathrm{~d}^{-1}$ in the upper layer and $287 \mathrm{mg} \mathrm{C} \mathrm{m}^{-2} \mathrm{~d}^{-1}$ in the lower layer (Table 3), with the sources ultimately being the particle biomasses in both layers, via the DOC pools. Bacterial biomasses were estimated at 1179 and $986 \mathrm{mg} \mathrm{C} \mathrm{m}^{-2}$, respectively, in the upper and lower layers (Table 3 ). It should be noted that some unknown fraction of the bacterial biomass in each layer was also included in the total particle biomass in each layer, as a consequence of the bulk analysis of total particle biomass; thus, particle biomass and bacterial biomass are not additive in Fig. 7, nor does the difference between particle biomass and bacterial biomass leave bacteria-free particle biomass. Our estimates from earlier SCBS data and those of Lee \& Fuhrman (1987) suggest that about $70 \%$ of the bacteria would be retained by the GF/F filters used for particle biomass. However, we did not make a direct estimate of bacterial carbon in POC samples.

The rates at which bacterial carbon entered the sinking fluxes from both layers remain unquantified at this time, and are noted in Fig. 7 by the letters $A$ and $C$. The residual loss from the combined upper and lower photic zone particle biomasses was approximately the difference between the measured particle flux at $100 \mathrm{~m}$ ( $259 \mathrm{mg} \mathrm{C} \mathrm{m}^{-2} \mathrm{~d}^{-1}$ ) and the sum of the fluxes due to feces production and sinking of bacterial carbon (i.e. the sum of $39+69+\mathrm{A}+\mathrm{C}$ ). The residual loss was the result of (1) the settling of particles that had been 
processed by carnivores and microheterotrophs, and/or (2) the direct settling of particles (including phytoplankton and detritus) that had not been put through grazers or had not been converted to bacterial carbon. Rates of these unquantified residual losses are given by the letters $B$ and D in Fig. 7.

With no measurements of $A, B, C$ and $D$ in Fig. 7 it was not possible to partition those fluxes into upper and lower photic layers, nor was it possible to differentiate their contributions to the total flux at $100 \mathrm{~m}$. Their combined contribution was ca $151 \mathrm{mg} \mathrm{C} \mathrm{m} \mathrm{m}^{-2} \mathrm{~d}^{-1}$, however, which was the difference between the tatal carbon flux ( $259 \mathrm{mg} \mathrm{C} \mathrm{m}^{-2} \mathrm{~d}^{-1}$ ) and the combined fecal carbon flux (108 $\mathrm{mg} \mathrm{C} \mathrm{m}^{-2} \mathrm{~d}^{-1}$ ). The $151 \mathrm{mg} \mathrm{C} \mathrm{m}^{-2} \mathrm{~d}^{-1}$ was approximate because the $108 \mathrm{mg} \mathrm{C} \mathrm{m}^{-2} \mathrm{~d}^{-1}$ fecal settling rate was approximate. Some of the fecal matter produced by macrozooplankton may have been small enough to remain suspended in the photic zone.

Fig. 7. is a great oversimplification of the real ocean Additional detail is provided in Fig. 8, where 4 components of particulate carbon biomass in the upper photic zone are shown; phytoplankton las 50 times chlorophyll a), bacteria (assuming all is included in total particle biomass), microflagellates, and organic detritus (by difference). The separate day (D) and night (N) zooplankton biomass measurements are given for the 3 size classes, plus the rates of fecal carbon production. In Fig. 7 the fecal production rates were combined for simplicity, to give an overall rate for all 3 size classes of zooplankton.
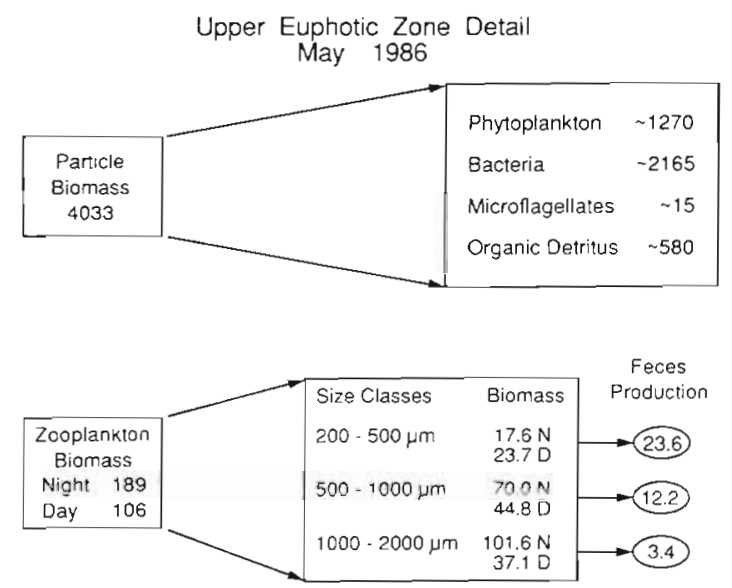

Fig. 8. Further detail of the biomasses $\left(\mathrm{mg} \mathrm{C} \mathrm{m}^{-2}\right)$ included as particle biomass and zooplankton biomass in the upper photic layer in Fig. 7. Also included are fecal carbon production rates ( $\mathrm{mg} \mathrm{C} \mathrm{m}^{-2} \mathrm{~d}^{-1}$ ) by each size class of zooplankton

Carbon flow diagrams such as those in Fig. 7 were prepared for each of the 5 cruises. Some common themes have emerged. First, loss of particulate carbon from the particle biomass pools $\left(259 \mathrm{mg} \mathrm{C} \mathrm{m}^{-2} \mathrm{~d}^{-1}\right.$ in Fig. 7) was always greater than the new production rate calculated as carbon (188 $\mathrm{mg} \mathrm{C} \mathrm{m}^{-2} \mathrm{~d}^{-1}$ in Fig. 7). Second, zooplankton food intake rate was always greater than the new production rate, in both layers of the photic zone, and was usually above $20 \%$ of primary production in both photic layers. Food intake rate was usually less than $5 \%$ of the particulate carbon biomass in both photic layers, however. Third, most of the primary production was recycled within the photic zone, implying that most of the phytoplankton production was grazed by animals too small to be caught in $200 \mu \mathrm{m}$ mesh, or by macrozooplankton that produce slowly settling fecal debris. Estimates of bacterial demand for organic carbon suggested that about half to the primary production was ultimately processed in the photic zone by bacteria. How the particulate organic matter produced by the phytoplankton was converted to dissolved organic matter utilized by bacteria is an important question. In general, microflagellates graze upon bacteria and presumably constrain the accumulation of bacterial biomass. Microflagellates and ciliated protozoans probably graze on small phytoplankton as well. Typically more than half of the phytoplankton biomass in Santa Monica Basin passes a $5 \mu \mathrm{m}$ sieve and is therefore of the proper size to be grazed by protozoans. The biomass of microflagellates was small in May 1986, however (Fig. 8), and its role in constraining phytoplankton and bacterial biomass could not have been large at that time. This condition may have been related to the high primary production, shallow nitracline and major role of macrozooplankton grazing in May 1986.

Our spring and autumn budget attempts appear to be encouraging. Summer and winter budgets are now needed for a more complete assessment of the carbon and nitrogen dynamics of the upper waters in Santa Monica Basin, in addition to critical measurements of microheterotroph transformation of the particulate carbon field through all seasons.

Acknowledgements. The research presented here was supported by grants from the U.S. Department of Energy, Office of Health and Environmental Research (DE-FG05-85ER60340 to L.F.S.; DE-FG05-85ER60335 and -88ER60628 to M.R.L.; DE-FG05-85ER60336 to R.W.E.; and DE-FG05-85ER60337 to F.A. and A.F.C.J, and by a grant from the National Science Foundation, Ocean Sciences Division (OCE 86-13685 to R.W.E.). We gratefully acknowledge the contributions of $B$. Cho, D. Craven, V Fagemess C.-A. Huh, S. Moore, W. Peterson, J. Postel, and E. Renger, in both sample collection and data analysis

\section{LITERATURE CITED}

Alldredge, A. L., Silver, M. W (1988). Characteristics, dynamics and significance of marine snow. Prog Oceanogr 20: 41-82

Azam, F. (1986). Nutrient cycling and food web dynamics in the Southern California Bight: the microbial foodweb. In: 
Eppley, R. W (ed.) Phytoplankton dynamics of the Southern California Bight. Springer-Verlag, Berlin, p. 274-288

Bascom, W. (ed.) (1983-1984). Southern California Coastal Water Research Project Biennial Report. Long Beach, California

Carlucci, A. F., Eppley, R. W. Beers, J. R. (1986a). Introduction to the Southern California Bight. In: Eppley R. W. (ed.) Phytoplankton dynamics of the Southern California Bight. Springer-Verlag, Berlin, p. 1-12

Carlucci, A. F., Craven, D. B., Robertson, K. J., Henrichs, S. M. (1986b). Microheterotrophic utilization of dissolved free amino acids in depth profiles of Southern California Borderland basin waters. Oceanologica Acta 9: 89-96

Cho, B. C., Azam, F. (1988). Major role of bacteria in biogeochemical fluxes in the oceans interior. Nature, Lond. 332: 441-443

Christofferson, K., Jesperson, A.-M. (1986). Gut evacuation rates and ingestion rates of Eudiaptomus graciloides measured by means of the gut fluorescence method. J. Plankton Res. 8: 973-983

Coale, K. H. Bruland, K. W. (1985). ${ }^{234} \mathrm{Th}:{ }^{238} \mathrm{U}$ disequilibria within the California Current. Limnol. Oceanogr. 30: 22-33

Dagg, M. J., Wyman, D. D. (1983), Natural ingestion rates of the copepods Neocalanus plumchrus and $N$. cristatus calculated from gut contents. Mar. Ecol. Prog. Ser. 13: 37-46

Eppley, R. W. (1986). People and the plankton. In: Eppley R. W (ed.) Phytoplankton dynamics of the Southern California Bight. Springer-Verlag, Berlin, p. 289-303

Eppley, R. W., Holm-Hansen, O. (1986). Primary production in the Southern California Bight. In: Eppley, R. W. (ed.) Phytoplankton dynamics of the Southern California Bight. Springer-Verlag, Berlin, p. 176-215

Eppley, R. W., Reid, F. M. H., Stewart, E. (1984). Length of phytoplankton species patches on the Southern California shelf. Cont. Shelf Res. 3: 259-266

Eppley, R. W., Renger, E. H. (1988). Nanomolar increase in surface layer nitrate concentration following a small wind event. Deep Sea Res. 35: 1119-1125

Eppley, R. W., Renger, E. H., Betzer, P. R. (1983). The residence time of particulate organic carbon in the surface layer of the ocean. Deep Sea Res. 30: 311-323

Eppley, R. W., Renger, E. H., Harrison, W. G. (1979). Nitrate and phytoplankton production in southern California coastal waters. Limnol. Oceanogr 24: 483-494

Eppley, R. W., Stewart, E., Abbott, M. R., Heyman, U. (1985) Estimating ocean primary production from satellite chlorophyll: introduction to regional differences and statistics for the Southern California Bight. J. Plankton Res. $7: 57-70$

Fuhrman, J. A., Azam, F. (1982). Thymidine incorporation as a measure of heterotrophic bacterioplankton in marine surface waters: evaluation and field results. Mar. Biol. 62: $1-12$

Garside, C. (1982). A chemiluminescent technique for the determination of nanomolar concentrations of nitrate, nitrate and nitrite, or nitrite alone in seawater. Mar. Chem. 11: 159-167

Goldman, J. C., McCarthy, J. J., Peavey, D. G. (1979). Growth rate influence on the chemical composition of phytoplankton in ocean waters. Nature, Lond. 279: 210-215

Harrison, W G., Platt, T., Lewis, M. R. (1987), f-ratio and its relationship to ambient nitrate concentration in coastal waters. J. Plankton Res. 9: 235-248

Hickey, B. M. (1986). Circulation over the Santa Monica/San Pedro Basin and shelf. In: West Coast Environmental Program, California Basin Study (CaBS) Prog. Rpt 3

Hobbie, J. E., Daley, R. J., Jasper, S. (1977). Use of nuclepore filters for counting bacteria by fluorescence microscopy. Appl. environ. Microbiol. 33: 1225-1228
Honjo, S. (1980). Material fluxes and modes of sedimentation in the mesopelagic and bathypelagic zones. J. mar Res. 38: 53-97

Huh, C.-A., Beasley, $\Upsilon$ M. (1987). Profiles of dissolved and particulate thorium isotopes in the water column of coastal Southern California. Earth Planet. Sci. Lett. 85: 1-10

Ikeda, T (1974). Nutritional ecology of marine zooplankton. Mem, Fac. Fish. Hokkaido Univ. 22: 1-97

Jackson, G. A. (1986). Physical oceanography of the Southern California Bight. In: Eppley, R. W (ed.) Phytoplankton dynamics of the Southern California Bight. Springer-Verlag, Berlin, p. 13-52

Kiorboe, T., Mohlenberg, F., Riisgard, H. U. (1985). In situ feeding rates of planktonic copepods. A comparison of four methods. J. exp. mar. Biol. Ecol. 88: 67-81

Knauer, G. A., Martin, J. H., Bruland, K. W. (1979). Fluxes of particulate carbon, nitrogen, and phosphorus in the upper water column of the northeast Pacific. Deep Sea Res. 26: $97-108$

Knauer, G. A., Karl, D. M., Martin, J. H., Hunter, C. N. (1984). In situ effects of selected preservatives on total carbon, nitrogen and metals collected in sediment traps. J. mar Res. 42: 445-462

Landry, M. R., Hassett, R. P., Fagerness, V., Downs, J., Lorenzen, C. J. (1984). Effect of food acclimation on assimilation efficiency of Calanus pacificus. Limnol. Oceanogr. 29: 361-364

LeBorgne, R. (1982). Zooplankton production in the eastern tropical Atlantic Ocean: net growth efficiency and P:B in terms of carbon, nitrogen and phosphorus. Limnol. Oceanogr 27: 681-698

Lee, S., Fuhrman, F. A. (1987). Relationships between biovolume and biomass of naturally derived marine bacterioplankton. Appl. environ. Microbiol. 53: 1298-1303

Li, W. K. (1986). Experimental approaches to field measurements: methods and interpretation. In: Platt, T., Li, W. K. (ed.) Photosynthetic picoplankton. Can. Bull. Fish. Aquat. Sci. 214: 251-286

Mackas, D., Bohrer, R. (1976). Fluorescence analysis of zooplankton gut contents and an investigation of diel feeding patterns. J. exp. mar. Biol. Ecol. 25: 77-85

Martin, J. H., Knauer, G. A., Karl, D. M., Broenkow, W. W (1987). VERTEX: carbon cycling in the northeast Pacific. Deep Sea Res. 34: 267-285

Mullin, M. M. (1986). Spatial and temporal scales and patterns. In: Eppley, R. W. (ed.) Phytoplankton dynamics of the Southern California Bight. Springer-Verlag, Berlin, p. $216-273$

Nelson, J. R., Beers, J. R., Eppley, R. W., Jackson, G. A., McCarthy, J. J., Soutar, A. (1987). A particle flux study in the Santa Monica-San Pedro Basin off Los Angeles: particle flux, primary production, and transmissometer survey. Cont. Shelf Res. 7: 307-328

Prézelin, B. B., Alldredge, A. L. (1983). Primary production of marine snow during and after an upwelling event. Limnol. Oceanogr. 28: 1156-1167

Small, L. F., Fowler, S. W., Moore, S. A., LaRosa, J. (1983). Dissolved and fecal pellet carbon and nitrogen release by zooplankton in tropical waters. Deep Sea Res. 30: $1199-1220$

Small, L. F., Fowler, S. W., Unlu, M. Y. (1979). Sinking rates of natural copepod fecal pellets. Mar Biol. 51: 233-241

Smith, P. E., Eppley, R. W. (1982). Primary production and the anchovy population in the Southern California Bight: comparison of time series. Limnol. Oceanogr. 27: 1-17

Strickland, J. D. H., Parsons, T. R. (1972). A practical handbook of seawater analysis. Bull. Fish. Res. Bd Can. 167 
Welshmeyer, N. A., Lorenzen, C. A. (1985). Chlorophyll budgets: zooplankton grazing and phytoplankton growth in a temperate fjord and the Central Pacific Gyres. Limnol. Oceanogr. 30: 1-21

This article was submitted to the editor
Williams, P. M. (1986). Chemistry of the dissolved and particulate phases in the water column. In: Eppley, R. W. (ed.) Phytoplankton dynamics of the Southern California Bight. Springer-Verlag, Berlin, p. 53-83

Manuscript first received: November 11, 1988

Revised version accepted: May 21, 1989 